\title{
Yapım Sürecinde Atık Yönetimi: Yapım Sürecinde Atık Yönetiminin Sistem Yaklaşımıyla Ele Alınması
}

\author{
Havva AKSEL ${ }^{1 *}$ (D) , ikbal ÇETINER 2 (D) \\ ORCID 1: 0000-0003-4253-2550 \\ ORCID 2: 0000-0001-5034-7895 \\ ${ }^{1}$ Mimar Sinan Güzel Sanatlar Üniversitesi, Mimarlık Fakültesi, Mimarlık Bölümü, 34427, İstanbul, Türkiye. \\ ${ }^{2}$ Kırklareli Üniversitesi, Mimarlık Fakültesi, Mimarlık Bölümü, 39100, Kırklareli, Türkiye. \\ *e-mail: havva.aksel@msgsu.edu.tr
}

Öz

Yapı üretimi birçok aktör ve nesnenin sürecin farklı aşamalarında dâhil olduğu endüstriyel bir üretim süreci olup; atık üretiminde önemli etkiye sahiptir. Yapım süreci ise; birbirleriyle ilişkili birçok sistem ve alt sistemden oluşan "Yapı üretimi sisteminin" alt sistemini niteliğindeki "yapım sisteminin" bir öğesidir. Yapım sürecinde üretilen atık miktarı ve türü, uygulanan proje, yapım teknolojisi, işçilik vb. birçok parametreye bağlı olarak değişkenlik göstermektedir. Bu durum yapım sürecindeki atık yönetiminin anlaşılabilirliği ve uygulanabilirliği açısından önemli bir kısıt oluşturmaktadır. Çalışmanın amacı; yapım sürecinde atık yönetiminin sistemli bir şekilde uygulanabilirliğini sağlamak üzere kavramsal bir çerçeve sunmak yoluyla bir "Atık Yönetimi Sistemi (YS-AYS)'nin oluşturulmasıdır. Çalışma, literatür verilerinin sistem yaklaşımıyla ele alınması yöntemiyle gerçekleştirilmiş olup, analiz, sentez ve değerlendirme aşamalarından oluşmaktadır. YS-AYS yapım sistemi ile atık yönetimine ilişkin ögeleri kapsamakta olup, açık bir sistem olma özelliğindedir. Ayrıca yapım sürecinin çok değişkenli yapısı ile atık yönetim işlemlerinin çeşitliliği nedenleriyle birçok potansiyel alt sistemi bünyesinde barındırmadır.

Anahtar Kelimeler: Yapım süreci, atık yönetimi, yapı üretimi, yapım sistemi, yapısal atık

\section{Waste Management in Construction Process: A System Approach for Waste Management in Construction Process}

\begin{abstract}
Building production, in which various actors and objects are involved at different stages, is an industrial production process having prominent role in waste generation. Construction process $(C P)$ is an element of the "construction system" which constitutes a sub-system of "building production system" consisting of many interrelated systems and subsystems. The quantity and type of wastes generated in CP are affected by various factors such as project, construction technology, labor, etc., which creates an important constraint in terms of understandability and applicability of the construction process waste management. The study aims to set up a "Construction Waste Management System (CWMS)" presenting a conceptual framework to provide systematic applicability of waste management practices in CP. CWMS is an open system constructed in the input-processoutput relationship based on system approach. Additionally, it includes many potential subsystems due to the multivariate nature of $\mathrm{CP}$ and the diversity of waste management processes.
\end{abstract}

Keywords: Construction, waste management, building production, construction system, construction waste

Atıf/Citation: Aksel, H, Çetiner, İ. (2021). Yapım Sürecinde Atık Yönetimi: Yapım Sürecinde Atık Yönetiminin Sistem Yaklaşımıyla Ele Alınması. Journal of Architectural Sciences and Applications, 6 (1), 206-226. DOI: $10.30785 / \mathrm{mbud} .887749$ 


\section{Giriş}

Endüstriyel üretim süreçleri, doğal kaynak tüketimi, enerji tüketimi, küresel ısınma ve iklim değişikliği, atık oluşumu vb. birçok çevresel etkiye neden olmaktadır. Yapı endüstrisi tüm bu çevresel etkiler içerisinde atık üretiminde önemli bir etkiye sahiptir. Dünyadaki birçok şehirde düzenli depolama alanlarına iletilen toplam atığın yaklaşık \% 10-30'unu Yapı Üretimi Kaynaklı Katı Atıklar (YÜKA) oluşturmaktadır (Li, 2013; European Commission, 2018). YÜKA'lar Avrupa'da en fazla üretilen atık türlerinden birini temsil etmekte olup, Avrupa Birliği içerisinde her yıl 500 milyon ton YÜKA üretilmektedir (European Commission, 2020). Eurostat verilerine göre, ekonomik aktivitelere bağlı atık oluşum oranları içerisinde, YÜKA oluşum oranı 2012 yılında \%33 iken, bu oran 2016'da \%36,4'e yükselmiştir (Eurostat, 2012; Eurostat, 2016). Ülkemizde yıllık YÜKA oluşum miktarının 2023 yılı itibariyle 300 milyon tona ulaşacağı tahmin edilmektedir (ÇŞB, 2017). Bu bağlamda YÜKA'lar için sürdürülebilir yönetim stratejilerinin geliştirilerek, atık miktarının azaltılması ve döngüsel bir ekonomi yaratılması çevresel açıdan önem göstermektedir.

Doğru yaklaşımlar veya stratejilerle, YÜKA'lardan ekonomik, sosyal ve çevresel açıdan birçok fayda sağlamak mümkündür. Örneğin YÜKA'ların geri kazanımı (yeniden kullanım ve geri dönüşüm) ekonomik açıdan yeni iş sahalarının açılması, endüstriyel üretim maliyetinde tasarruf; sosyal açıdan sağlık problemlerinin ve yoksulluğun önlenmesi; çevresel açıdan ise hava ve su kalitesinin iyileştirilmesi, doğal kaynakların korunması ve sera gazı salınımlarının azaltılması gibi birçok fayda sağlamaktadır (UNEP, 2015, European Commission, 2020).

Literatürde YÜKA'lara ilişkin birçok çalışma yer almaktadır. Bu çalışmalar; atık oluşum miktarları ve nedenlerini belirlemeye yönelik çalışmalar; atık azaltmaya yönelik çalışmalar; atık yönetim uygulamalarının tespitine yönelik çalışmalar vb. olmak üzere çeşitlenmektedir. Bu çalışmaları genel olarak; (i) yapım, yıkım ve yenileme süreçlerinde oluşan atıkları malzeme düzeyinde değerlendiren ve (ii) yapım ve yıkım süreçlerinde oluşan atıkları süreç içerisinde değerlendiren çalışmalar olarak iki temel kategoride sınıflandırmak mümkündür. Literatürde atık oluşumu ve yönetimini yapım sürecinde değerlendiren çalışmalara, malzeme düzeyinde değerlendiren çalışmalara kıyasla oldukça az sayıda rastlanmaktadır. Ayrıca literatürde yapı üretim sürecinde atık yönetimini bütüncül bir yaklaşımla ele alarak, yapı üretim sürecinin bir bileşeni olan yapım süreci içerisinde açıklayan bir çalışmaya rastlanılmamıştır. Bu bağlamda çalışmanın amacı yapı üretim sürecinin bir bileşeni olan yapım süreci ile atık yönetimi konusunun kavramsal açıdan anlaşılabilirliğinin sağlanabilmesi için sistemler yaklaşımıyla ele alınarak iki farklı sistemi bütünleştiren bir "Atık Yönetimi Sisteminin" oluşturulmasıdır. Böylelikle çalışmanın; yapım sürecinde atık yönetim uygulamalarına ilişkin kavramsal bir çerçeve sunarak, şantiyelerde atık yönetiminin sistemli bir şekilde uygulanmasına katkı sağlayacağı düşünülmektedir.

\section{Materyal ve Yöntem}

Sistemler aralarında anlamlı ilişkiler bulunan birbirlerine bağımlı öğeleri içeren kavramsal veya fiziksel varlıklar ya da bütünlerdir (Ackoff, 1968; Berköz, 1975; Bayazıt, 1994). Bir bütünü sistem olarak nitelendirebilmek için öncelikle o bütünü oluşturan öğeler arasındaki ilişki düzenine, karşılıkı etkileşimlerine ve bu öğelerin oluşturduğu bütünsel davranışlara bakmak gerekir (Berköz, 1975). Sistem bütünsel bir organizasyon olup; sistemin öğeleri öznel nitelikleri yerine, sistem içerisindeki dağılma ve düzenlemeleri aracılığı ile sistemin bileşenlerini oluştururlar. Bir sistem; (i) Sistem hedefleri, (ii) Sistem kaynakları, (iii) Sistem bileşenleri, (iv) Sistem çevresi, (v) Sistem yönetimi öğelerinden oluşmaktadır (Aksoy, 1974; Berköz, 1975; Özkan, 1976). Sistemler çevre ile ilişki durumlarına göre açık ve kapalı olmak üzere iki şekilde sınıflandırılırlar. Açık sistemler çevre ile sürekli bir ilişki içerisindedir. Açık sistemlerde çevre ile enerji ve malzeme akışı bulunmaktadır, malzeme sistem dışına çıkabilir, sistem içine girebilir. Kapalı sistemde ise açık sistemlerin aksine, sistem çevre etkilerine kapalıdır ve yalnız iç ilişkiler ile denge halinde bulunmaktadır (Bayazıt, 1994).

Çalışma sistem yaklaşımıyla ele alınmış olup; analiz, sentez ve değerlendirme aşamalarından oluşmaktadır (Şekil 1). Analiz aşaması literatüre ait veriler içermekte olup, iki bölümden oluşmaktadır. ilk olarak yapı üretimi sistemi ile yapı üretimi sisteminin bir alt sistemi olan yapım sistemi ele alınmış ve sistemlerin işleyişine yönelik modeller ortaya konulmuştur. İkinci olarak ise atık yönetimi ile yapım 
sürecinde atık yönetimi konusu irdelenerek konuyla ilgili veriler ortaya konulmuştur. Sentez aşamasında; yapım sistemi ile yapım süreci atık yönetimine ilişkin çalışmanın analiz aşamasında elde edilen veriler bütünleştirilerek "Yapım Süreci Atık Yönetim Sistemi (YS-AYS)" ortaya konulmuştur. YSAYS sistem yaklaşımı kapsamında girdi-süreç-çıktı ilişkisi içerinde kurgulanmıştır. Son aşama olan değerlendirme aşamasında ise; çalışmanın sonuçlarına yer verilmiştir.

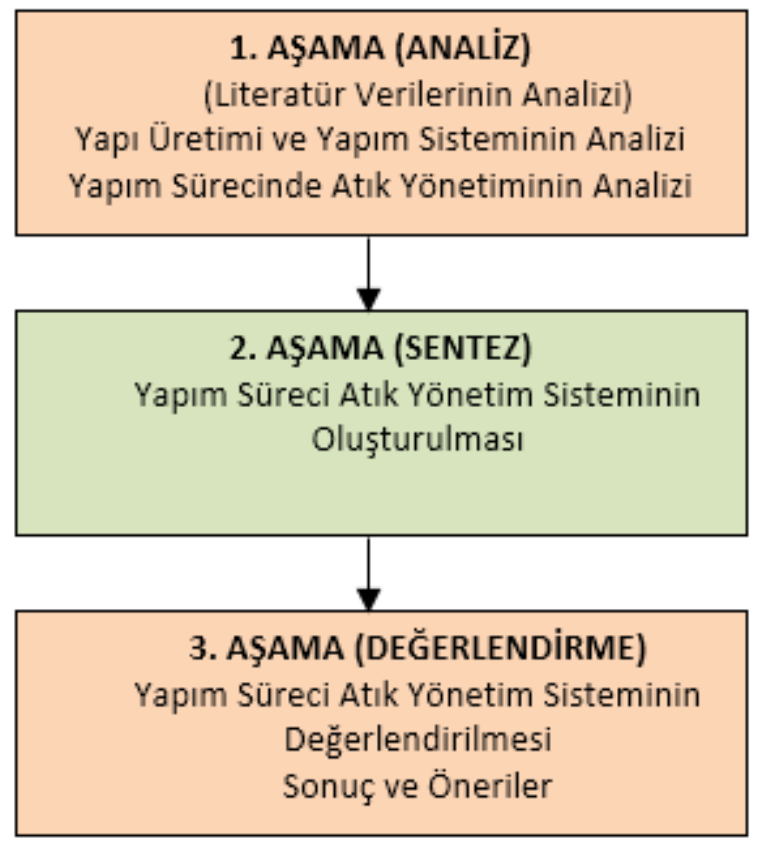

Şekil 1. Çalışmanın akışı

\section{Bulgular ve Tartışma}

\subsection{Yapı Üretimi ve Yapım Sistemi (Analiz)}

Yapı üretimi sistemi ve yapım sistemi kavramlarının anlaşılabilmesi için, öncelikle yapım ve yapı kavramlarının ele alınması yerinde olacaktır. Yapım; yapma işi, inşa, imal, konstrüksiyon ya da diğer bir ifadeyle, yapı ürününü oluşturmak için yapılan eylemler ve bu eylemlerin birbirleri ile ilişkisi olarak tanımlanabilir (Türkçü, 2004; TDK, 2020). Yapılar ise yapı üretim sürecinin bir çıktısı olup, birbirleri ile ilişkili ve entegre birçok sistem ve alt sistemin parçasını oluşturmaktadır (Ching Francis, 2008). Bu başlık altında yapı üretimi sistemi ile yapım sistemi ayrı ayrı ele alınarak modellenmiştir.

\subsubsection{Yapı üretimi sistemi}

Yapı üretimi; birden fazla aktörün ve nesnenin sürecin farklı aşamalarında dahil olduğu, fiziksel çevreyi düzenlemek için yürütülen örgütlü bir çabadır. Üretimde kullanılan kaynaklar "girdi"; kaynakların mal ve hizmete dönüştürülmesi işlemi "süreç"; elde edilen mal ve hizmet ürün "çıktı" olarak nitelendirilmektedir. Yapı üretimi sistemi kaynakları; sistemin kullandığı ve dönüştürerek tükettiği tüm nesne, olgu ve bilgilerdir (Sey ve diğerleri, 1987; Aksoy, 1974; Berköz, 1975; Özkan, 1976). Yapı üretim süreçlerinde rol alan aktörler ise; müşteri, yönetici, yüklenici, alt yüklenici, tedarikçi, imalatçı-üretici, tasarımcı, proje yöneticisi, yapım yöneticisi, kalite kontrolcü, güvenlik koordinatörü ve danışmanlar olarak özetlenebilir (TSE-EN ISO 12006-2, 2020).

Yapı üretimi sistemi literatür verileri doğrultusunda girdi, süreç ve çıktı ilişkisi içinde kurgulanmış olup, Şekil 2'de sunulmuştur. Şekil 2'ye göre Yapı üretim süreci; (i) Girişim-Planlama-Programlama, (ii) Tasarım, (iii) Gerçekleştirme (Yapım), (iv) Dağıtım ve (v) Kullanım süreçlerinden oluşmakta olup, sistem içerinde her bir aşamaya etki eden girdiler sözü geçen süreçler tarafından dönüşüme uğratılarak çıktılara dönüştürülmektedir. Mevzuat, sektör yapılanması, politik sistem, doğal çevre, alt yapı vb. öğeler ise yapı üretimi sisteminin çevresini oluşturmaktadır. Literatürde yapı üretim sürecine ilişkin; sistemin açık ya da kapalı olmasına, üretimde yer alan işlemlere, yapıların strüktürel sistemine, üretim büyüklüğüne (tek tek üretim, kümesel üretim vb.), üretim yerine (yerinde yapım; önceden fabrikada, şantiyede, atölyede vb. üretim), endüstrileşme aşamasına (geleneksel, çağdaş yapım vb.) ve yapımda 
kullanılan temel malzemelere (betonarme sistemler, ahşap sistemler vb.) göre olmak üzere çeşitli sınıflandırmalar yer almaktadır (Özkan, 1976).

ÇEVRE: Mevzuat, sektör yapılanması, politik sistem, doğal çevre, alt yapı vb. öğeler.

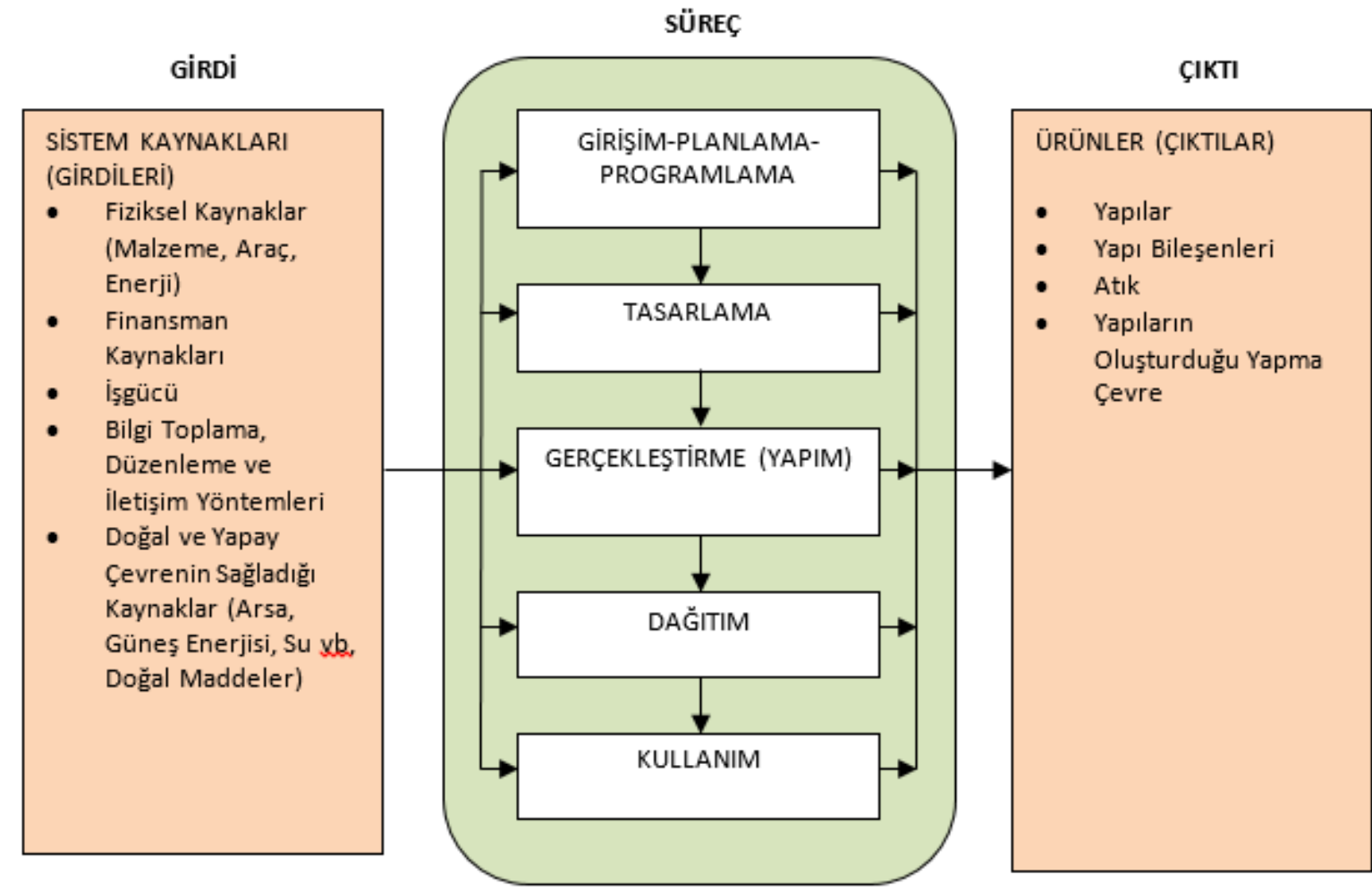

SISTEM SINIRI

Şekil 2. Yapı üretimi sistemi (Sey ve diğerleri, 1987 ile Özkan, 1976'dan uyarlanmıştır).

\subsubsection{Yapım sistemi}

Yapım sistemi, yapı üretimi sisteminin alt sistemlerinden birini oluşturmakta olup, "tüm yapı elemanlarının ve bu elemanların bir araya gelme olasılıklarının toplamı"; "binayı oluşturan elemanların bir araya getirilmesinde izlenen süreç" ve "uygulanan üretim, teknoloji, kural ve yöntemler" olarak tanımlanmaktadır (Türkçü, 2004).

Yapım süreci, uygulanan proje, yapım tekniği ve teknolojisi, malzeme, işçilik, araç vb. birçok değişkeni bünyesinde barındıran, tasarımcıdan, yükleniciye; alt yükleniciden, tedarikçiye çok sayıda paydaşın dahil olduğu karmaşık bir fiziksel üretim sürecidir (Galipoğulları, 2016). Bu bağlamda yapım sisteminde girdi ve çıktılar sözü geçen değişkenlere göre farklılaşmaktadır. Yapım sistemi girdi, süreç ve çıktı ilişkisi içerisinde kurgulanmış olup, Şekil 3'te sunulmuştur. Şekil 3'e göre yapım sistemi girdilerini (i) Fiziksel kaynaklar (iş̧̧ilik, araç, malzeme), (ii) Enformasyon ve (iii) Finansman oluştururken; "yapılar ve atıklar" sistem çıktılarını oluşturmaktadır. Yapım sistemi süreçleri ise; (i) İ̧̧ ve İşlemler, (ii) Temel Değişkenler şeklinde sınıflandırılmıştır. Yapım sistemi öğelerine ait bilgiler ilgili başıklar altında açıklanmıştır. 


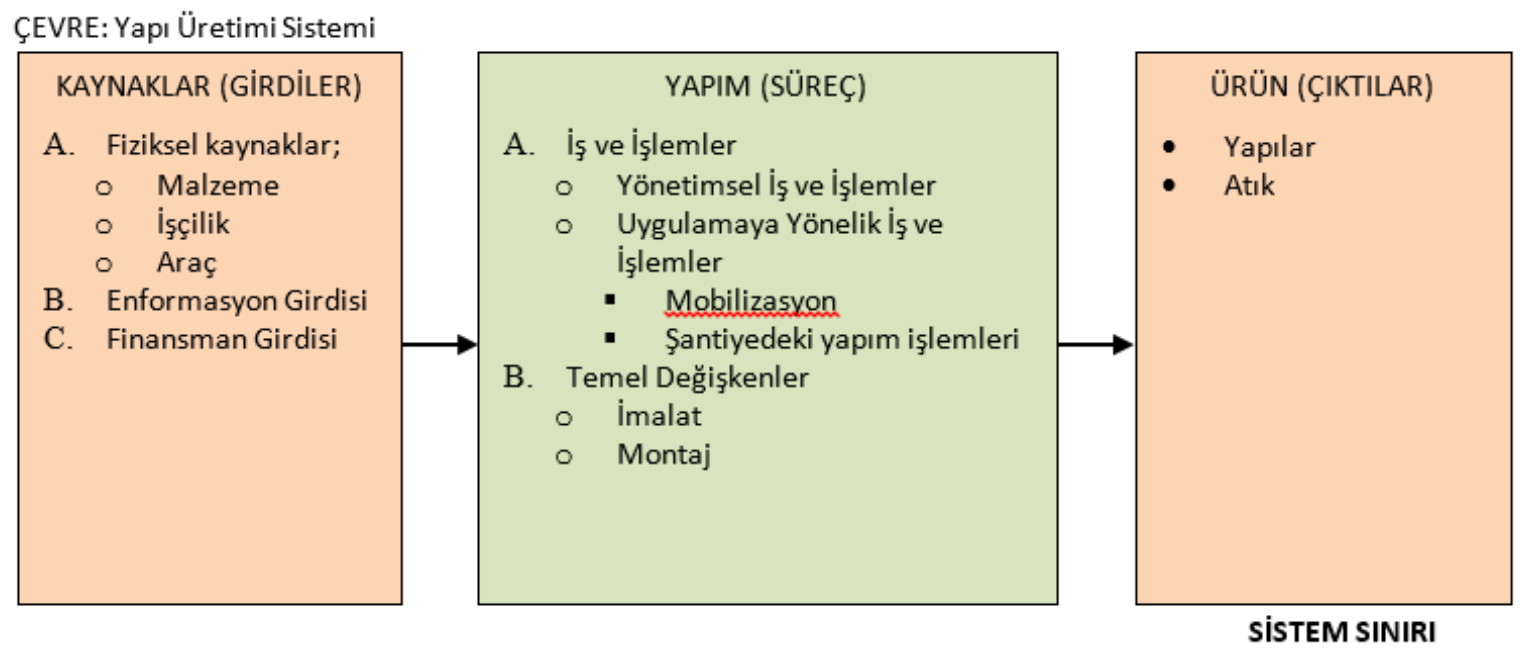

Şekil 3. Yapım sistemi (Özkan, 1976 ile TSE EN ISO 12006-2, 2020'den uyarlanmıştır).

\subsubsection{Yapım sistemi hedefi}

Bir sistemin hedefi ulaşıımak istenen sonuç veya sonuçlar olarak tanımlanmaktadır (Özkan, 1976). Yapım sistemi, kullanıc gereksinimlerini karşılamak üzere tasarlanan yapma çevreyi dış ve iç çevreden fiziksel olarak ayırmakta olup, yapının gerçekleştirilmesi (üretilmesi) hedefine yöneliktir. Yapım sistemi, yapının gerçekleştirilebilmesi için sistem çevresinden sağlanan kaynaklardan yararlanmaktadır.

\subsubsection{Yapım sistemi kaynakları}

Yapım sistemi kaynakları; fiziksel kaynaklar, enformasyon girdisi ve finansman girdisi olmak üzere üç başlık altında gruplandırılmıştır.

\section{Yapım sistemi fiziksel kaynakları;}

Sistem çevresine bağlı olarak yapımda yer alan fiziksel kaynaklar; malzeme, işçilik ve araç olarak üç ana başlık altında toplanmaktadır (Özkan, 1976).

Malzeme Girdisi: Malzeme Eriç (2016) tarafından "bir yapının bünyesine giren ve o yapının üretim ve kullanım süreci içerisinde biçimlenişini sağlayan, kullanıcıların konforunu düzenleyen her tür işlenmemiş, yarı veya tam işlenmiş maddeler" olarak tanımlanmıştır.

Balanlı (1997) yapı malzemesini diğer bir isim ile yapı gereci olarak adlandırmış olup, "doğal ve yapay süreçler sonunda oluşan, tanımlanacak bir geometrik biçimi olmayan kütlesel temel ürünler" (örneğin taş, ahşap, beton, harç vb.) olarak tanımlamıştır. Balanlı (1997)'ya göre; doğada her amaca uygun gereç bulunmamakta ve gereçler genellikle doğadaki biçimleri ile yapı üretimi sürecine dahil olamamaktadır. Çeşitli işlemlerden geçirilen doğal kaynaklar farklı bitirilmişlik düzeylerinde ve farklı biçimlerde yapı ürünlerine dönüştürülmektedir. Bu ürünler üretim, bitirilmişlik ve işlevlerine göre; gereç (malzeme), parça, bileşen, öğe, eleman, birim ve ünite düzeylerinde olup, yapının fiziksel/maddesel boyutunu oluşturmaktadır.

Türkçü (2004) malzemeyi bir yapının oluşturulmasında kullanılan doğal veya yapay ürünler olarak tanımlamış olup, malzemeler biçimsel yönden biçimlendirilmiş veya biçimlendirilmemiş olarak ikiye ayrılmaktadır. Biçimlendirilmemiş malzemeler, çakıl, çimento, kum, agrega gibi kesin geometrik biçimi olmayan doğal veya mamul ürünlerdir. Biçimlendirilmiş malzemeler ise üretim sırasında şekil kazanmış olan malzemeler olarak tanımlanmış olup, bu malzemeler yapı bileşeni olarak adlandııılmıştır (Türkçü, 2004). Türkçü, yapı bileşenini (şekil kazanmış yapı malzemesi) "profil bileşen, birim bileşen ve bileşik bileşen" olarak üç gruba ayırmaktadır. Profil bileşenler, en kesitleri tanımlı olup, üçüncü boyutta değişmektedir. Bu gruba örnek olarak borular, kutu profiller vb. verilebilir. Birim bileşenler; üç boyutu da tanımlı ve yan yana gelerek bir yapı elemanını oluşturan veya kaplayan bileşenlerdir. Bu gruba örnek olarak tuğla, beton briket, kiremit vb. verilebilir. Bileşik yapı bileşenleri ise; bünyelerinde biçimlendirilmemiş yapı malzemeleri ile profil ve birimsel yapı bileşenlerinin bir bütün içerisinde bir araya getirilmesiyle üretilmektedir. Bunlara örnek olarak kapı ve pencere doğramaları, dolaplar vb. verilebilir. Yapı elemanları (yapı öğesi) Türkçü tarafından; mekânın tamamını veya büyük bir kısmını 
tanımlayan (döşeme, çatı, temel vb.), mekânı kısmi olarak sınırlayan (kolon, kiriş vb.), bağlayıcıbirleştirici işlevde olabilen (pencere, kapı, merdiven vb.) yapı parçaları olarak tanımlanmıştır (Türkçü, 2004).

Aktarıldığı üzere literatürde yapım sürecinin fiziksel kaynaklarından biri olan malzemenin bitirilmişlik düzeyleriyle ilgili tam bir dil birliği bulunmamaktadır. Örneğin kapı ve pencereler Balanlı’ya göre yapı bileşeni olarak ele alınırken, Türkçü (2004) tarafından yapı elemanı (öğesi) olarak ele alınmıştır. Yapım süreci malzeme girdisi, farklı bitirilmişlik düzeylerinde olabilmektedir. Çalışma kapsamında; kavram karışıklığının önüne geçebilmek amacıyla, "malzeme" kavramı tüm bitirilmiş düzeylerini (gereç, parça, bileşen ve eleman) kapsayacak şekilde kullanılmıştır.

İşçilik ve Araç Girdisi: Yapım sürecinde yer alan dönüşüm süreçlerinin (fiziksel, kimyasal) gerçekleştirilebilmesi için çeşitli işçilik ve araçlara gereksinim duyulmaktadır. Yapım sürecinde gereksinim duyulan işçilik ve araçlar:

- Malzemelerin korunması için gerekli iş̧̧ilik ve araçlar,

- Malzemelerin desteklenmesi için gerekli işçilik ve araçlar,

- Malzemelerin kullanılması, elle ve makinelerle taşınması ile ilgili iş̧̧ilik ve araçlar

- Malzemelerin biçimlendirilmesine ilişkin iş̧̧ilik ve araçlar

- Kazma ve delmeye ilişkin iş̧̧ilik ve araçlar

- Malzemenin yerine konması, inşaat ve montaj ile ilgili iş̧̧ilik ve araçlar

- Bitirme işlemleri ile ilgili işçilik ve araçlar,

- Temizlik işleri ile ilgili işçilik ve araçlar

- $\quad$ iki veya daha fazla işle ilgili işçilik

olarak sıralanabilir (CBC sınıflandırma sistemi-Özkan, 1976). Şantiyelerde kullanılan araçlara (makine ve ekipmanlara) örnek olarak; kamyon, vinç, dozer, kepçe, kompresör, konkasör, konveyör vb. verilebilir (Baytop, 2019).

\section{Enformasyon ve Finansman girdileri}

Enformasyon Girdisi: Yapım işlerinin yürütülmesi çeşitli sözleşme ve dokümanların hazırlanması ile olanaklı olmaktadır (Galipoğulları, 2016). Bu bağlamda yapım işlerinde kullanılan tüm bu sözleşme ve dokümanların hazırlanabilmesi için aktörler arasında kullanılacak ortak bir dile gereksinim duyulmaktadır. Standartlaştırımış bir terminoloji oluşturularak, dil birliğinin sağlanabilmesi amacıyla yapı üretiminde, ulusal düzeylerde çeşitli sınıflandırma sistemleri geliştirilmiştir. Sınıflandırma yapı üretiminde iletişim ve koordinasyonun sağlanması, teknik şartnameler vb. dokümanlar ile maliyet hesaplamalarında önemli rol oynamakta olup, ulusal sınıflandırma sistemlerine örnek olarak; $\mathrm{Cl} / \mathrm{SfB}$ (Ingiltere), Uniclass (İngiltere), MasterFormat (Canada) ile SfB (İsveç) verilebilir (Ekholm ve Häggström, 2011; Lou ve Goulding, 2008). Bu sistemlerden bazıları uluslararası alanda da kabul görmüştür. Türkiye'de Mimarlar Odası tarafından, Yapı Araştırma Enstitüsü-TÜBITAK tarafından SfB sınıflandırma sisteminden yararlanılarak hazırlanmış olan Y.A.E. sınıflandırma sistemi kullanılmaktadır.

Gelişen teknolojiye paralel olarak yapı üretimi de hızlanmış olup, tüm bu üretim sürecinin hızına cevap verecek bir enformasyon sisteminin oluşturulması bir zorunluluk haline gelmiştir (Kanoğlu, 1994). Yapı marketlerinin küreselleşmesi, bilgisayarla bütünleşik yapı üretim sürecinin yaygınlaşması, özellikle de $C A D$ ve BIM'in piyasaya sürülmesiyle yapı üretiminde, uluslararası projelerde ve yapı elemanları ticaretinde ulusal sınıflandırma sistemleri arasında çeviri yapılması ya da ortak sistemler geliştirilmesi gibi yeni gereksinimler ortaya çıkmıştır. Bu bağlamda Uluslararası Standartlar Örgütü (International Organization for Standardization-ISO) tarafından yapı üretiminde ayrıntılı sınıflandırma tablolarının geliştirilmesi için bir çerçeve sunan ISO 12006-2 standardı yayınlanmıştır (Ekholm ve Häggström, 2011; Lou ve Goulding, 2008). ISO 12006-2, Türk Standartları Enstitüsü tarafından uyarlanarak TSE EN ISO 12006-2 (Bina yapımı-Yapım işlerine ilişkin bilgilerin organizasyonu-Bölüm 2: Sınıflandırma için çerçeve bilgi) standart numarası ile kabul edilmiştir. 
Finansman Girdisi: Yapım sürecinde yer alan kaynakların sağlanması için gereksinim duyulan parasal kaynaklar olarak tanımlanmaktadır (Sey ve diğerleri,1987).

\subsubsection{Yapım sistemi bileşenleri}

Sistem bileşenleri; her çeşit nesne olgu ve bilgiyi kapsayan "girdiler", girdilerin dönüştüğü "süreçler" ve süreçler sonucu oluşan yeni nesne olgu ve bilgileri içeren "çıktılar", "sistem değişkenleri" ile "geri besleme ve kontrol" olarak sıralanmaktadır (Özkan, 1976). Yapım sistemi girdileri fiziksel kaynaklar, enformasyon ve finansman girdileri olmak üzere ilgili başlıklar altında açıklanmış olup, yapım sistemi bileşenlerinden, süreç, çıktı ve değişkenler ile geri besleme ve kontrol akışta ele alınmıştır.

Süreç (Yapım): Süreç kelimesi üzerinde çalışılan bir şeyin bir durumdan başka bir duruma dönüştürülmesi şeklinde tanımlanabilir (Özkan 1976). Yapım süreci nesneye uygulanan birbirini takip eden veya eş zamanlı gerçekleşen kademeli dönüşüm süreçlerinden oluşmaktadır. Nesnelerin ilk dönüşüm evresi, doğal durumlarından hammadde haline dönüşme süreciyle başlar. İşlenmeye hazır hammaddelere dönüşen nesneler, yapım süreci içerisinde bir dizi dönüşüme uğrayarak, süreçler sonunda yapının birer parçasını oluştururlar. Yapım sürecinde kademeli olarak gerçekleşen dönüşüm süreçlerinde her bir nesnenin dönüşüm süreci sonunda ulaşmış olduğu varoluş biçiminin, bir önceki varoluş biçiminden ekonomik açıdan daha değerli olduğu söylenebilir (Aral, 1979).

Çıktı: Yapım sürecinin fiziksel çıktılarını kabaca binalar ile yollar, köprü vb. yapılar ile yapım atıkları oluşturmaktadır. Yapıların fiziksel olarak var edildiği alanlar şantiye olarak adlandırılır (Chudley ve Greeno, 2006). Yapım atıkları farklı tür, form, nitelik ve bitirilmişlik düzeyi ve miktarlarda oluşabilmektedir.

Değişkenler: Yapım sistemi, imalat ve inşaat ve/veya montaj olmak üzere iki temel değişkeni içermektedir (Özkan, 1976). İmalat işlemi ister yerinde ister ön üretim şeklinde yapılsın üretim üç temel süreç ile yürütülmektedir. Wachsmann (1961) yapı üretim süreçlerini çıkartma, ekleme ve biçimlendirme süreçleri olarak üç sürece ayırmaktadır (Özkan, 1976; Wachsmann, 1961). Çıkarma; doğrudan ayırma ve içinden çıkartma ile malzemenin biçimlendirilmesi süreçleridir. Bu süreçler; kesme, öğüterek çıkarma, vurarak delme, oyarak delme, rendeleme, zımparalama, parlatma gibi süreçleri içermektedir. Ekleme; organik birleşim (genellikle yapıştırma, soğuk ve sıcak pres gibi), kaynakla birleşim, mekanik birleşim (vidalama, bulonlama, perçinleme, kıvırarak birleştirme gibi) işlemlerini içermektedir. Biçimlendirme; yeniden biçimlendirme, plastik biçimlendirme ve döküm süreçlerini kapsamaktadır (Özkan, 1976).

Geri besleme ve kontrol: Sistem hedefleri ile zorunluluklara göre oluşturulan ölçütler ile çıktılardan beklenilen performans niteliklerini karşılaştıran bir alt sistem görevi görmektedir. Kontrol girdiler, süreç ve çıktılar üzerinden yapılmaktadır (Özkan 1976; Sey ve diğerleri, 1987). Bu bağlamda yapım sisteminde geri besleme ve kontrole örnek olarak yapı ürününün performans ölçütlerinin çeşitli yönetmelik, şartname vb. uygunluğunun kontrolü verilebilir.

\subsubsection{Yapım sistemi yönetimi}

Yapım sürecinde tüm süreçler ve paydaşlar arasında iletişimin sağlanması yapım sürecinin kalitesi açısından oldukça önemlidir. Bu bağlamda, yapım yönetimi ve proje yönetimi olmak üzere iki temel kavram karşımıza çıkmaktadır. Proje yönetimi; tasarımdan, fizibilite, yapının tamamlanması ve işletmesine kadar geçen süre içerisindeki tüm aşamaları açıklayan bir bilgi ve uygulama paketidir (Galipoğulları, 2016). Projenin tanımlanması, planlanması, uygulanması ve tamamlanması aşamalarından oluşmaktadır (Çetiner, 2007). Yapım yönetimi ise; projenin inşaatı ile ilgili bölümü kapsamakta olup, projenin ihale edilmesinden yüklenicinin yapıyı işletmeye hazır hale getirmesine kadar olan süre içerindeki faaliyetlerin tümünü kapsamaktadır (Galipoğulları, 2016; Kanoğlu, t.y.). Kanoğlu (t.y.) tarafından yapım yönetimi, bir yapım projesinin işverenin öngördüğü süre, bütçe ve kalitede üretilmesini sağlamak üzere, başından sonuna kadar sürecin, planlanması, yürütülmesi ve denetlenmesi işlemleri olarak tanımlamaktadır. Tüm bu işlemler, yapım sürecinde oluşabilecek problemleri öngörebilmek ve bu problemlere çözüm üretebilmek; iş gücü ve ekipmanın etkin kullanımını sağlamak, projenin finansmanına esas oluşturan nakit akışının yönetimine iliş̧in ön veri sağlamak; projeyi oluşturan alt eylemlere ilişkin iş gücü, araç, malzeme kaynakları ile süre ve maliyet 
tahminleri yapmak ve projede yer alan eylemlerin yürütülebilmesi için gerekli organizasyon ve iş bölümünü gerçekleştirebilmek amaçlarıyla kullanılmaktadır (Kanoğlu, t.y.).

\subsubsection{Yapım sistemi çevresi}

Çevre sistemin bağlı olduğu üst sistem ile bu sisteme ait diğer alt sistemlerden meydana gelmektedir (Sey ve diğerleri, 1987). Bu bağlamda yapım sisteminin çevresini "Yapı Üretimi Sistemi" oluşturmaktadır.

\subsection{Yapım sürecinde atık yönetimi (analiz)}

Atıklar "üretimden tüketime kadar olan tüm aşamalarda ortaya çıkan ve kullanııının artık işine yaramayan maddelerin tamamı" olarak tanımlanmaktadır (TDK, 2020). Atıklar, herhangi bir tüketim veya üretim aktivitesi sonucu ortaya çıkmakta olup; önlenmesi, azaltılması veya yönetilmesi gereken nesnelerdir. İnsan eliyle gerçekleştirilen aktivitelerin tamamında atık üretilmekte olup, üretilen atık miktarı ve çeşitleri; kültürel farklııklar, gelir seviyesi, tüketim alışkanlıkları, yaşanılan coğrafya, yaşanılan coğrafyadaki doğal kaynak çeşitliliği vb. birçok faktöre bağlı olarak değişkenlik göstermektedir (Christensen, 2011; Pires ve diğerleri, 2011; UNEP, 2005).

Atıklar; kaynağına (kökenlerine), doğasına, fiziksel, mekanik, biyolojik ve kimyasal özelliklerine göre sınıflandırılmaktadır. Kaynaklarına göre atıklar; (i) Evsel Atıklar (Konutlarda üretilen atık, kurumsal, ticari ve servis atıkları); (ii) Endüstriyel Atıklar (Çeşitli üretim aktiviteleri, yapım ve yıkım aktiviteleri, kimya, otomotiv, enerji, maden ve tarım atıkları); (iii) Medikal Atıklar ve (iv) Diğer Atıklar (Evsel, endüstriyel veya medikal atıklar dışında kalan atıklar) şeklindedir (Chang ve Pires, 2015). Atık içeriği atığın kaynağına göre çeşitlenmektedir. Örneğin evsel atıklar kağıt, plastik ve cam içeriği açısından zenginken, endüstriyel atıklar, endüstriyel üretim sürecine göre içerik açısından çeşitlilik göstermektedir (Chang ve Pires, 2015). Çalışma kapsamında yapı üretimi kaynaklı bir atık türü olan ve yapım sürecinde oluşan atıklar için "yapım atığı" kavramı kullanıımıştır. Yapım atığı; beton, ahşap, metal, alçı, karton vb. birçok malzemeyi içerebilmekte olup (Llatas, 2013);

- Hafriyat Atığı (Kum, taş, toprak, çamur vb.),

- Ambalaj Atığı (Ahşap paletler, plastik ve karton ambalajlar vb.),

- Yapım Sırasında Kullanılan Malzemelerin Atıkları (Beton, seramik, çelik, demir, alüminyum, bakır, ahşap, cam, plastik, alçı, asfalt vb.),

- Zararlı Atıklar,

- Diğer Atıklar (Yukarıdaki sınıflandırma dışında kalabilecek her türlü atık)

olarak beş başlık altında sınıflandırılabilir. Yapım atığı; genellikle zararlı (kimyasal), etkisiz (inert) ve etkili (non-inert) olmak üzere üç temel özellikteki malzemelerden oluşmaktadır. Zararlı atıklar, insan sağlığına ya da çevreye bir veya birden fazla zararı olan atıklardır. Kirlenmiş toprak ve dip tarama çamurları, yanıcı, toksik veya tahriş edici özellikte olan yapıştırıcılar, solunabilir lif formunda asbest bazlı malzemeler, PCB ve CFC içeren malzemeler ve araçlar, cıva içeren aydınlatma ürünleri, çözücü, boya ve yapıştırıcı gibi tehlikeli maddelerin kutuları ve ambalajları zararlı atıklara örnek verilebilir. Etkisiz atıklar, herhangi bir fiziksel, biyolojik ve kimyasal dönüşüme uğramayan atıklar olarak tanımlanmakta olup; bu atıklardan öncelikle fiziksel olmak üzere, kimyasal veya biyolojik dönüşümler sebebiyle herhangi bir zararı olmayan atıklar ise zararsız atıklar olarak nitelendirilmektedir. Tuğla, beton, kum vb. atıklar etkisiz özellik gösteren atıklardır. Plastik, cam, kâğıt, ahşap, bitkiler ve diğer organik malzemeler ise etkili özellik gösteren atıklardır (Yuan ve diğerleri, 2013; Chang ve Pires, 2015; European Commission, 2016).

Farklı özelliklerdeki atıklar için farkı yönetim stratejilerinin geliştirilmesi gerekmektedir. Bu bağlamda atık yönetiminde doğru planlama, tasarım ve işletim için atık yığınlarının özelliklerinin ve miktarının belirlenerek net bir şekilde tanımlanması gerekmektedir (Tchobanoglous ve diğerleri, 1993; Chang ve Pires, 2015). Atık yönetimi uygun depolama, toplama, taşıma ve bertaraf teknikleri ve sistemlerinin uygulanmasını kapsayan bütüncül bir yaklaşımdır (Pichtel, 2005). Atık yönetiminde; Atık Yönetim Hiyerarşisi, Kirletici Öder illkesi, Genişletilmiş Üretici Sorumluluğu, Önleyici İlke, İnsan Sağlığının ve 
Çevrenin Korunması, Öz Yeterlik ve Yakınlık IIlkesi, Sıfır Atık İlkesi, Bütünleşik Ürün Politikası, Döngüsel Ekonomi vb. çeşitli stratejiler uygulanmaktadır (Christensen, 2011; Chang ve Pires, 2015; European Commission, 2020). Bu stratejilerden literatürde "3R prensibi (reduce, recycle, reuse)" olarak da adlandırılan Atık Yönetim Hiyerarşisi (AYH) 1980 yılından bu yana uluslararası alanda yaygın olarak benimsenen ve çevresel açıdan tercih sırasına dayalı bir yaklaşımdır (Chistrensen 2011; Chang ve Pires, 2015). AYH'ye göre atığın önlenmesi/azaltılması her zaman hiyerarşinin en üst basamağında olup, bertaraf problemlerini indirgeyeceğinden çevresel açıdan en etkin basamaktır. Eğer atığın önlenmesi/azaltılması mümkün değilse, AYH'ye göre daha sonra tercih edilmesi gereken uygulama atığın yeniden kullanımıdır. Yeniden kullanım uygulamaları atık ürünlerin veya bileşenlerin yaşam ömrü sonunda aynı amaca yönelik olarak, herhangi bir ön işlem görmeden, temizleme, onarım veya kontrol işlemleri uygulanarak tekrar kullanılması işlemidir. AYH'ye göre yeniden kullanımın mümkün olmadığı durumlarda ise, bir sonraki uygulama olarak geri dönüşüm tercih edilmelidir. Geri dönüşüm; atık bir malzemenin, yeni bir ürünün üretim sürecine malzeme girdisi olarak dahil olmasıyla geri kazanımının sağlanması şeklinde tanımlanabilir. Diğer bir ifadeyle geri dönüşüm atıkların işlenerek ilk üretildiği kullanım amacına yönelik ürünlere veya farklı kullanım amaçlarına yönelik ürünlere, malzemelere veya nesnelere dönüştürmeye yönelik herhangi bir geri kazanım işlemi şeklinde tanımlanabilir. Geri dönüşüm uygulamaları; atığın ayrılması, depolanması, taşınması ve işlenmesi gibi ek süreçleri içermekte, bu süreçler enerji tüketimi kaynaklı ek çevresel etkilere neden olabilmektedir. Bu nedenle geri dönüşüm $\mathrm{AYH}^{\prime}$ de yeniden kullanımdan sonra tercih edilmesi gereken bir geri kazanım yöntemidir (Peng ve diğerleri, 1997; Gorgolewski ve diğerleri, 2006; European Parliament and Council, 2008; Chong ve Hermreck, 2010; Atık Yönetimi Yönetmeliği, 2015).

AYH günümüze kadar çeşitli kuruluşlarca tanımlanmış ve atık önleme/azaltma, yeniden kullanım ve geri dönüşüm uygulamaları için çevresel tercih sırası sabit tutularak çeşitli hiyerarşiler oluşturulmuştur. Örneğin UNEP'e göre AYH, öncelikli tercih sırasına göre; Atık Önleme, Yeniden Kullanım, Geri dönüşüm, Atıktan Enerji Kazanımı ve Bertaraf şeklinde sıralanmıştır (UNEP, 2010). USEPA'ya göre AYH, tercih sırasına göre; Malzemelerin Yeniden Kullanımı, Malzemelerin Geri dönüşümü, Kompostlama, Enerji Kazanımlı Yakma, Enerji Kazanımsız Yakma ve Atığın Düzenli Depolama Sahasına Gönderilmesi şeklindedir (Pichtel, 2005). Avrupa Komisyonuna göre ise, AYH öncelikli tercih sırasına göre; Atık Önleme, Yeniden Kullanım İçin Hazırlama, Geri Dönüşüm, Malzeme Geri Kazanım ve Bertaraf şeklindedir (Şekil 4) (European Commission, 2016).

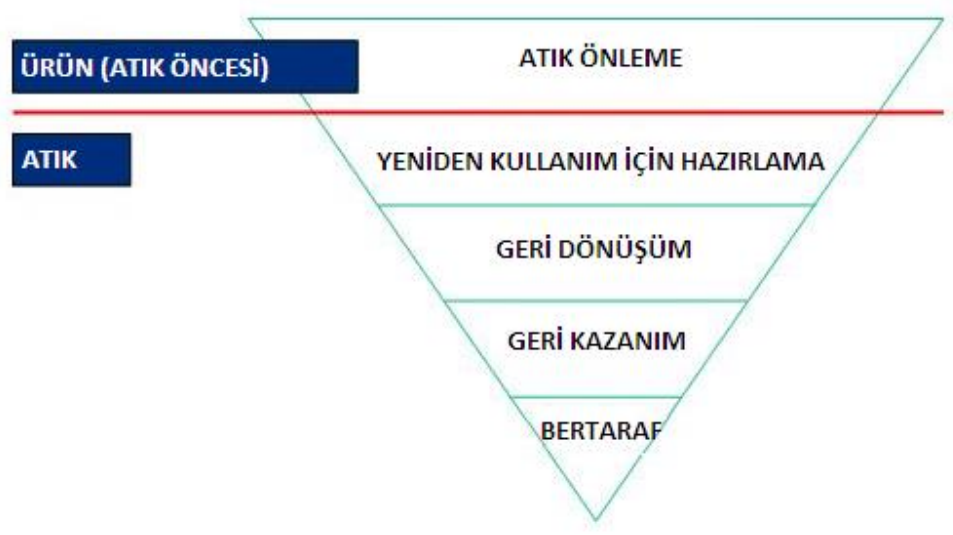

Şekil 4. Atık yönetim hiyerarşisi (European Commission, 2016).

Avrupa Birliği içerisinde atık yönetimi genel olarak AYH prensipleri çerçevesinde yürütülmekledir. Bununla birlikte Avrupa Birliği üyesi ülkeler arasında ulusal düzeyde, özel yönetim planlarının veya stratejilerinin uygulanması yaygın bir yaklaşımdır. Avrupa Birliği üyesi ülkelerde atık yönetimi konusunda ortak politikalar ve amaçlar oluşturulması hedeflenmektedir. Bu bağlamda 2008 yılında Avrupa Komisyonu tarafından yayınlanan Atık Çerçeve Direktifi'nde 2020 yılı için Birlik üyesi ülkelerde YÜKA'ların geri kazanım oranlarının \%70 olması hedeflenmiştir. Ancak 2020 yılında Avrupa Birliği üyesi ülkelerde geri kazanım oranı ortalama $\% 50$ oranında kalmıştır. Birlik üyesi bazı ülkelerde ise geri kazanım oranı ortalamanın oldukça üzerindedir. Örneğin Eurostat 2017 verilerine göre; Hollanda, Almanya ve Danimarka'da geri dönüşüm oranı \%80'i aşmış durumdadır. Avrupa Komisyonu tarafından 
2024 yılında YÜKA'lar için geri kazanım hedefinin güncellenmesi planlanmaktadır (European Commission, 2018; European Parliament and Council, 2018; Gálvez-Martos ve diğerleri, 2018).

Ulusal düzeyde özel yönetim planlarının veya stratejilerinin uygulanmasının, birlik içinde atık yönetimi konusunda heterojen sonuçlar doğurduğu söylenebilir. Örneğin İspanya'da şantiyeler için atık yönetim planının hazırlanması yasal bir zorunluluktur. Aynı zamanda beton atıklar için 80 ton, tuğla atıklar için 40 ton, metal atıklar için 2 ton olmak üzere; atık oluşumunun söz konusu miktarları aşması durumunda atıkların ayrıştırıması yasal bir zorunluluktur. Almanya'da atık yönetim planları ülkenin bazı bölgelerinde yıkım uygulamaları için uygulanmaktadır. Bununla birlikte Almanya 1996 yılından beri geri dönüşüme oldukça önem vermektedir. 2012 yılı itibariyle Almanya'da YÜKA'lar \%91.2 oranında geri dönüştürülmüştür. Hollanda'da atıklar için vergi ve harç uygulanmakta olup, geri dönüşüm oranı 2000 yılından bu yana \%90'ın üzerindedir. İngiltere'de WRAP vb. atık yönetim planına ilişkin araçların geliştirilmesi, atıklar için ton başına vergi uygulanması gibi uygulamalar geri dönüşüm oranlarını yükseltmiştir. Avusturya'da bu oran $\% 85$ 'in üzerindedir. Birlik içerisinde hammaddeye ulaşım konusunda sıkıntı çeken ülkelerde geri dönüşüm oranlarının ve geri dönüşüm konusunda farkındalığın daha yüksek olduğu bilinmektedir (Gálvez-Martos ve Istrate, 2020; Gálvez-Martos ve diğerleri, 2018). Birlik üyesi ülkeler arasında atık yönetimi konusunda farklııılar oluşmasının nedenleri; atık miktarı ve atıkların kaynağına ilişkin veri eksikliği, atıklar için uygulanan vergi ve harçların düşük olması, geri dönüşüm tesislerinin yetersiz sayıda ve nitelikte olması, geri dönüştürülmüş ürünlere duyulan güvensizlik, hammadde fiyatları vb. olarak özetlenebilir (Osmani ve Villoria-Sáez, 2019).

Avrupa Birliği dışındaki ülkelerde de AYH yaygın olarak uygulanmaktadır. Japonya'da Atık Yönetimi 3R prensipleri uygulanmakta olup, atıklar 2000 yılından bu yana yürürlükte olan Yapı Malzemeleri Geri dönüşüm Yasası'na göre yönetilmektedir. Japonya'da yıllık YÜKA oluşum oranı (hafriyat atığı hariç) toplam atık oluşumunun \%20'si kadardır. Ülkedeki YÜKA geri kazanım oranı ise yaklaşık \%96'dır (MLIT, 2019; Tam, 2009). Amerika Birleşik Devletleri'nde (ABD) ise yine atık yönetim uygulamaları AYH'ye göre yürütülmektedir. EPA verilerine göre; ABD'de 2018 yılında 600 milyon ton YÜKA üretilmiş olup, $A B D$ geri dönüşüm oranı \%70-\%95 arasındadır (EPA, 2021; Xiao ve diğerleri, 2015; Huang, 2018). Çin'de YÜKA'lar toplam atığın \%30 ile \%40'ını oluşturmaktadır. Bu atıklar gelişigüzel bir şekilde atılabilmekte veya düzenli depolama alanlarına gönderilmektedir. Çin en çok YÜKA üreten ülkelerden biri olup, YÜKA'ların sadece \%5'i geri kazanılmaktadır (Gálvez-Martos ve Istrate, 2020; Huang, 2018).

Ülkemizde atık yönetimi; Avrupa Birliği'ne uyum çerçevesinde Avrupa Birliği komisyon kararlarına uygun olarak 2015 yılında yürürlüğe giren ve AYH'yi benimseyen, Atık Yönetimi Yönetmeliği çerçevesinde yürütülmektedir. Atık Yönetimi Yönetmeliği'ne göre atık yönetimi; atığın oluşumunun önlenmesi, kaynağında azaltılması, yeniden kullanımı, atığın özelliklerine ve türüne göre ayrılması, biriktirilmesi, toplanması, geçici depolanması, taşınması, ara depolanması, geri dönüşümü, enerji geri kazanımı dâhil geri kazanılması, bertarafı, bertaraf işlemleri sonrası izlenmesi, kontrolü ve denetimi faaliyetlerinin tamamını içermektedir (European Commission, 2008; Atık Yönetimi Yönetmeliği, 2015). Şantiyelerde atık yönetiminin AYH'ye uygun olarak yönetilmesi tercih edilen bir yaklaşımdır. 2023 yılı itibariyle YÜKA oluşum miktarının 300 milyon tona ulaşacağı tahmin edilmektedir. Yakın zamanda geri kazanım oranlarına ilişkin yayınlanmış bir veri bulunmamakta olup; 2014 verilerine göre geri kazanılan ya da bertaraf edilen YÜKA miktarı yaklaşık 100 milyon tonun üzerindedir (ÇŞB, 2017).

\subsubsection{Yapım sürecinde atık önleme/azaltma}

Yapım sürecinde farklı miktar, tür, boyut ve özelliklerde birçok atık oluşmakta olup, oluşan bu atıkların miktarı ve türleri; uygulanan projenin türü, yapımda kullanılan malzemeler, kullanılan yapım tekniği ve teknolojisi, yerel piyasa koşulları, yükleniciye ait özelikler, uygulama ekibinin (uygulama, denetleme vb. konularda görev alan teknik personel) mesleki yetenekleri, işçilik gibi birçok parametreye bağlı olarak değişkenlik göstermektedir (Gavilan ve Bernold, 1994; Faniran ve Caban, 1998; Goodhew, 2016). Örneğin özel konut ve özel ticari projelerin yapımı sırasında, diğer proje türlerine göre yapımda standartlaşmış ürünlerin kullanımı azaldığından, daha fazla atık oluşmaktadır (Tam ve diğerleri, 2005). Bir diğer örnek ise; alt yapı projeleri, yol ve köprü vb. yapımında, konut vb. binalara göre daha az ambalaj atığı oluşmasıdır (Llatas, 2013). Bu bağlamda, şantiyelerde atık oluşumunun önlenmesi/azaltılmasına yönelik önlemler alınabilmesi için öncelikle atığın kaynağının/kökeninin tespit edilmesi gerekmektedir (Gavilan ve Bernold, 1994; Tam ve Tam, 2006). Yapım atığının kaynağı/kökeni, 
Gavilan ve Bernold (1994) tarafından tasarım hataları, satın alma/tedarik hataları, yükleme/boşaltma ve depolama hataları, işlem-işçilik hataları, artık/fazlalık malzeme, listelenmeyen diğerleri olarak altı ana başlık altında sınıflandırılmıştır. Ekanayake ve Ofori (2004) yapım atığı oluşum nedenlerini; tasarımla; işlemlerle; malzemelerin taşınması ile ve tedarik ile ilgili olmak üzere dört ana başlık altında gruplandırmışlardır. Faniran ve Caban (1998), yapım atığı oluşum nedenlerini belirleyerek yapım atığııın azaltıımasına yönelik bir çalışma yürütmüşlerdir. Çalışmanın sonuçlarına göre; en etkili yapım atığı oluşum nedenleri tasarım değişiklikleri, artan malzemeler, ambalaj atıkları, geri kazanılamaz sarf malzemeleri, tasarım ve detaylandırma hataları ve kötü hava koşullarıdır. Osmani ve diğerleri (2008) literatürde yer alan yapım atığı oluşumu konusunu; atık kaynağı ve atık nedeni olarak ele almıştır (Çizelge 1).

Çizelge 1. Yapım atığı oluşum nedenleri ve kaynakları (Osmani ve diğerleri, 2008).

\begin{tabular}{|c|c|}
\hline Atık Kaynağı & Atık Nedeni \\
\hline Sözleşme & $\begin{array}{l}\text { Sözleşmede yer alan hatalar } \\
\text { Sözleşmede yer alan eksiklikler }\end{array}$ \\
\hline Tasarım & $\begin{array}{l}\text { Tasarım değişiklikleri } \\
\text { Tasarım ve detaylandırmada karmaşıklık } \\
\text { Detaylandırma ve tasarım hataları } \\
\text { Belirsizlik ve şartnameye uygunsuzluk } \\
\text { illetişim ve koordinasyon sorunları } \\
\end{array}$ \\
\hline Tedarik & $\begin{array}{l}\text { Sipariş hataları (şartnameye uygun olmayan ürün siparişi) } \\
\text { Yüksek ödenekler (az miktarda sipariş vermede yaşanan zorluklar) } \\
\text { Tedarikçi kaynaklı hatalar }\end{array}$ \\
\hline Nakliyat & $\begin{array}{l}\text { Nakliyat sırasında malzemenin hasar görmesi } \\
\text { Nakliye araçlarının şantiye içerisindeki ulaşım zorlukları } \\
\text { Malzemenin şantiye içerisinde boşaltılması sırasında zarar görmesi }\end{array}$ \\
\hline $\begin{array}{l}\text { Şantiye Yönetimi } \\
\text { Ve Planlama }\end{array}$ & $\begin{array}{l}\text { Atık yönetim planının olmaması } \\
\text { Planlama hataları (Üretilen atık miktarına uygun olmayan kararlar) } \\
\text { Bilgi aktarımı problemleri } \\
\text { Denetim ve kontrol problemleri }\end{array}$ \\
\hline Depolama & $\begin{array}{l}\text { Uygun olmayan depolama koşulları } \\
\text { Malzemelerin uygun olmayan şekilde depolanması } \\
\text { Malzemelerin uygulama alanından uzakta depolanması }\end{array}$ \\
\hline $\begin{array}{l}\text { Malzeme Taşıma- } \\
\text { Yükleme-Boşaltma }\end{array}$ & $\begin{array}{l}\text { Malzemelerin uygun koşullarda nakliyatı } \\
\text { Malzemenin uygun olmayan şekilde yüklenip boşaltılması } \\
\text { Malzemenin şantiye içerisinde uygun olmayan şeklide taşınması }\end{array}$ \\
\hline Şantiye Sahası İşlemleri & $\begin{array}{l}\text { İhmal nedeniyle oluşan kazalar } \\
\text { Kullanılmayan malzeme ve ürünler } \\
\text { Ekipman arızası } \\
\text { İşçilik kalitesi sorunları } \\
\text { Malzemenin yanlış kullanımı sonrası atığa dönüşmesi } \\
\text { Zaman baskısı } \\
\text { İş etiği problemleri }\end{array}$ \\
\hline Artma & $\begin{array}{l}\text { Uygulama işlemi kaynaklı atık (örneğin çimento harcının gereken miktardan } \\
\text { fazla hazırlanması) } \\
\text { Boyutlandırma amaçlı kesim atığı } \\
\text { Ekonomik olmayan biçimlerde malzemenin kesilmesi } \\
\text { Ambalaj atığı }\end{array}$ \\
\hline Diğer & $\begin{array}{l}\text { Hava koşulları } \\
\text { Vandalizm } \\
\text { Hırsızlık }\end{array}$ \\
\hline
\end{tabular}

Yapım sürecinde atığın önlenmesi/azaltılması, atığın kaynağına/kökenine göre çeşitli stratejilerin uygulanması ile mümkün olmaktadır. Örneğin Poon ve diğerleri (2004a)'e göre, şantiyelerde satın alınan malzemelere ilişkin teslimat ve ödemelerle ilgili kayıtların düzenli bir şekilde tutulması, atık oluşumunun önlenmesi/azaltılmasında önemli etkiye sahiptir. Ayrıca Poon ve diğerleri (2004b)'ne göre, şantiyenin temiz ve düzenli tutulması, malzemelerin siparişi ve depolamanın uygun şekilde yapılması; malzemelerin kaybolmasını ve/veya zarar görmesini engelleyerek atık oluşumunu azaltmakta ve daha güvenli bir şantiye ortamı sağlamaktadır. Ayrıca yapım atığı yönetiminde sözleşmeye bağlı etmenler de önemli rol oynamaktadır (Tam ve Tam, 2006). Faniran ve Caban (1998)'a 
göre, yapım sürecinde kullanılacak yapı malzemelerinin özelliklerinin teknik şartnamelere uygun şekilde tanımlanması ve şartnamelerin yüklenici tarafından kontrol edilmesi, yapım atığının önlenmesi/azaltılmasını sağlayan önemli bir yaklaşımdır. Osmani (2012)'ye göre yapım atığının önlenmesi/azaltılması müşteriler (yapı sahibi), tasarımcılar, yükleniciler ve tedarikçiler gibi farklı paydaşların katıımıyla mümkün olabilmektedir. Poon ve diğerleri (2004a)'ne göre yapım sürecinde tedarik edilen malzemelerin teslimat, yükleme ve boşaltma sırasında hasar görerek atık haline dönüşümünün önlenmesi için; tedarikçi, üretici, tasarımcı ve yüklenicilerin malzemelerin paketlenmesi, yüklenmesi, şantiyeye getirilmesi, boşaltılması aşamalarında şantiye olanakları da dikkate alınarak iş birliği içinde çalışmaları gereklidir. Ayrıca Yuan (2013b)'a göre iş̧̧i, mühendis vb. uygulayıcıların şantiyedeki davranış ve tutumları atık oluşumunda doğrudan etkilidir. Bu nedenle uygulayıcıların atık oluşumu ve yönetimine ilişkin farkındalıklarının geliştirilmesi, iş̧̧ilik ve uygulama hatalarının dolayısıyla atık oluşumunun önlenmesinde önemli bir etkendir (Yuan, 2013b). Poon ve diğerleri (2004b)'ne göre yüklenicinin, taşeronların ve şantiye çalışanlarının atık yönetimi ile ilgili uygulamalara yönelik gerekli eğitimleri alması da atık azaltma açısından etkili bir uygulamadır.

\subsubsection{Yapım sürecinde yeniden kullanım ve geri dönüşüm}

Yapım atığııın yeniden kullanımı ve geri dönüşümünün sağlanması için, öncelikle atıkların ayrılması gerekmektedir. Atık ayırma, atıkların içeriklerine ve karakteristik özelliklerine göre gruplandırılması şeklinde tanımlanmaktadır (Yuan ve diğerleri, 2013; Atık Yönetimi Yönetmeliği, 2015). Ayırma işlemi sırasında genellikle geri dönüştürülebilir atıklar gruplandırılmaktadır. Oluşan atıkların miktarı ve içeriğinin şantiyelere göre çeşitlenmesi sebebiyle, atık ayırma uygulamaları da projeden projeye veya şantiyeden şantiyeye farklılık göstermektedir. Örneğin altyapı projelerinde çoğunlukla, toprak ve çamur gibi etkisiz atıklar oluşmaktadır. Bu nedenle altyapı projesi şantiyelerinde, atık ayırma işlemleri nadiren gözlenmektedir (Yuan ve diğerleri, 2013). Atık ayırma uygulamaları, şantiye içinde (on-site sorting) diğer bir deyişle kaynakta ayırma ya da şantiye dışında (off-site sorting) olmak üzere iki şekilde gerçekleştirilmektedir. Yapım süreci atıklarının şantiye içerisinde ayrılması, atık ayırma işlemleri için işçi çalıştırılması gerekliliğini doğurmakta olup, bu durum yükleniciler açısından yapım süreci maliyetini arttıran bir etmendir (Poon ve diğerleri, 2001). Ayrıca atıkların şantiye içerisinde ayrılması, şantiyenin alansal olanakları ile doğrudan ilişkilidir (Wang ve diğerleri, 2010). Yeterli alanın bulunmadığı şantiyelerde, ayırma işlemlerinin şantiye dışında uygulanması tercih edilebilir bir yaklaşımdır. Ancak atıkların şantiye içerisinde (kaynağında) ayrılmaması durumunda, atık ayırma verimliliği düşmekte ve yapım atığı yığını içerisinde zararlı atıklar yer alabilmektedir. Atık yığını içerisinde zararlı atıkların yer alması, geri kazanım sırasında insan sağlığı ve çevresel açıdan risk oluşturmaktadır (European Commission, 2020; Poon ve diğerleri, 2001). Dolayısıyla yapım atığının şantiyede ayrılması çevresel açıdan tercih edilmesi gereken bir yaklaşım olmalıdır (Poon ve diğerleri, 2001; Yuan ve diğerleri, 2013). Ayrıca Poon ve diğerleri (2004b)'ne göre, atık ayırma sözleşmelerde yer alan yasal bir zorunluluk olmalıdır.

Şantiyelerde atıkların ayrılması için; borular vasıtasıyla toplama, konteynerlerde toplama ya da karmaşık ve düzensiz bir şekilde toplama vb. uygulamalar bulunmaktadır. Poon ve diğerleri (2004b)'ne göre; atıkların şantiyelerde karmaşık ve düzensiz bir şekilde toplanması, ayırma işlemleri sırasında problemler oluşturmakta ve atıkların birbirlerine temas ederek kirlenmelerine sebep olabilmektedir. Wang ve diğerleri, (2010)'a göre; atıkların birbirlerine bulaşması ayrıştırılabilirlik olanağını düşürmekte, dolayısıyla da atıkların geri kazanımını zorlaştırmaktadır.

Aksel Çiçekçi (2020) tarafından şantiyelerde atık yönetimi uygulamalarına ilişkin bir alan çalışması gerçekleştirilmiş olup, şantiyelerde yürütülen farklı atık yönetim uygulamalarına ilişkin bilgiler Çizelge 2 'de sunulmuştur. Çalışma sonuçlarına göre; ülkemizde şantiyelerde atıkların toplanması, ayrılıması ve geri kazanım uygulamaları genellikle yüklenicinin sorumluluğunda yürütülmektedir. Şantiyelerde atıkların atık yığını halinde toplanarak daha sonra tamamen veya kısmen ayırılması şeklinde bir uygulama yaygındır. Atıkların geri kazanımının arttırılarak çevresel açıdan en etkin faydanın sağlanabilmesi için, şantiyelerde atıkların kaynağında ayrı ayrı toplanması uygulamalarının ülkemizde yaygınlaşması gerekmektedir. Plastik, kâğıt ve karton artıkların geri dönüşümün sağlanabilmesi için geri dönüşüm firmaları ile yüklenici firmalar arasında yeterli bağlantıların olmadığı, bu durumun sözü geçen atıkların geri dönüşümünde önemli bir engel oluşturduğu ortaya konulmuştur. Ayrıca yeniden kullanım 
uygulamalarının genellikle aynı yüklenicilere ait şantiyeler arasında gerçekleştiği, atıkların yeniden kullanımının sağlanabilmesi için farklı firmalara ait şantiyeler arasında yeterli iş birliğinin bulunmadığı belirtilmiştir. Bu bağlamda, yeniden kullanımın sağlanması/yaygınlaşması için farklı firmalar arasında gerekli iletişim ağının kurularak iş birliklerinin arttırılması gerekmektedir.

Çizelge 2. Şantiyelerdeki atık yönetim uygulamaları (Aksel Çiçekçi, 2020'den uyarlanmıştır).

Uygulamaya Yönelik iş̧ ve işlemler

\begin{tabular}{|c|c|c|c|}
\hline İş ve İşlem & & Uygulama Şekli & Açıklama \\
\hline \multirow[t]{3}{*}{$\begin{array}{l}\text { Toplama- } \\
\text { Biriktirme }\end{array}$} & \multirow[t]{2}{*}{$\begin{array}{l}\text { Etkisiz ve } \\
\text { etkili atık } \\
\text { toplama }\end{array}$} & $\begin{array}{l}\text { Atık boruları (bacaları) } \\
\text { aracılığıyla toprak kotuna } \\
\text { iletilmesi }\end{array}$ & $\begin{array}{l}\text { Şantiyede atıkların üretildikleri alanda bir yığın veya küme } \\
\text { oluşturacak şekilde belirli bir kotta bir araya getirilmesi }\end{array}$ \\
\hline & & $\begin{array}{l}\text { Atıkların üretildiği } \\
\text { mekânlarda toplanması- } \\
\text { biriktirilmesi }\end{array}$ & $\begin{array}{l}\text { Atıkların üretildikleri mekânlarda veya katlarda toplanması- } \\
\text { biriktirilmesi }\end{array}$ \\
\hline & $\begin{array}{l}\text { Zararlı Atık } \\
\text { Toplama }\end{array}$ & $\begin{array}{l}\text { Zararlı atıkların üretildiği } \\
\text { mekânlarda toplanması- } \\
\text { biriktirilmesi }\end{array}$ & $\begin{array}{l}\text { Zararlı atıkların üretildiği mekânlarda toplanması- } \\
\text { biriktirilmesi. }\end{array}$ \\
\hline \multirow[t]{3}{*}{ Ayırma } & \multirow{3}{*}{$\begin{array}{l}\text { Atıkların } \\
\text { kaynağında } \\
\text { ayrııması }\end{array}$} & $\begin{array}{l}\text { Atıkların üretildiği } \\
\text { mekânlarda ayrılması }\end{array}$ & $\begin{array}{l}\text { Atıkların şantiye içinde üretildiği mekânlarda türlerine göre } \\
\text { ayrılması (konteynerler aracılığıyla) }\end{array}$ \\
\hline & & $\begin{array}{l}\text { Atıkların şantiye içinde } \\
\text { geçici depolama } \\
\text { alanlarında ayrılması }\end{array}$ & Atıkların geçici depolama türlerine göre ayrılması \\
\hline & & $\begin{array}{l}\text { Atıkların şantiye dışında } \\
\text { ayrılması }\end{array}$ & $\begin{array}{l}\text { Geçici depolama alanındaki atıkların üretildiği mekanlarda } \\
\text { türlerine göre ayrılması }\end{array}$ \\
\hline \multirow[t]{4}{*}{ Taşıma } & \multirow{2}{*}{$\begin{array}{l}\text { Etkisiz ve } \\
\text { etkili atık } \\
\text { taşıma }\end{array}$} & $\begin{array}{l}\text { Şantiye sahası içinde } \\
\text { taşınması }\end{array}$ & $\begin{array}{l}\text { Üretildiği kaynaktan biriktirme ve/veya depolama alanına } \\
\text { taşınması }\end{array}$ \\
\hline & & $\begin{array}{l}\text { Şantiye sahası dışına } \\
\text { taşıma }\end{array}$ & $\begin{array}{l}\text { Biriktirme ve/veya depolama alanından döküm alanlarına } \\
\text { taşınması }\end{array}$ \\
\hline & \multirow[t]{2}{*}{$\begin{array}{l}\text { Zararlı Atık } \\
\text { Taşıma }\end{array}$} & $\begin{array}{l}\text { Şantiye sahası içinde } \\
\text { taşınması }\end{array}$ & $\begin{array}{l}\text { Zararlı atıkların uygun koşullarda zararlı atık depolama } \\
\text { alanlarına taşınması }\end{array}$ \\
\hline & & $\begin{array}{l}\text { Şantiye sahası dışına } \\
\text { taşınması }\end{array}$ & $\begin{array}{l}\text { Zararlı atıkların zararlı atık depolama alanından şantiye } \\
\text { dışına taşınması }\end{array}$ \\
\hline \multirow[t]{2}{*}{ Depolama } & \multirow[t]{2}{*}{$\begin{array}{l}\text { Geçici } \\
\text { Depolama }\end{array}$} & $\begin{array}{l}\text { Şantiye sahası içinde } \\
\text { geçici depolanması }\end{array}$ & $\begin{array}{l}\text { Şantiyede yeterli alan bulunması durumunda, atıkların } \\
\text { üretilmesi sonrasında bertaraf edilmesine kadar geçen } \\
\text { sürede, şantiye sahası içinde uygun bir alanda uygun } \\
\text { koşullarda geçici olarak depolanması }\end{array}$ \\
\hline & & $\begin{array}{l}\text { Şantiye sahası dışında } \\
\text { geçici depolanması }\end{array}$ & $\begin{array}{l}\text { Şantiyede depolama için yeterli alan bulunmaması } \\
\text { durumunda, atıkların üretilmesi sonrasında bertaraf } \\
\text { edilmesine kadar geçen sürede şantiye içerisinde uygun bir } \\
\text { alanda uygun koşullarda geçici olarak depolanması }\end{array}$ \\
\hline
\end{tabular}

Yapım süreci atık ayırmayı etkileyen bir diğer önemli etken, geri dönüşüm ve yeniden kullanım pazarı olanaklarıdır (Wang ve diğerleri, 2010). Begum ve diğerleri (2006) tarafından atığın yeniden kullanımı ve geri dönüşümü ile elde edilen ekonomik kazancın; toplam proje bütçesinin $\% 2,5$ kadarı olduğu tahmin edilmektedir. Birçok atık malzemenin şantiyelerde ayrılması, dolayısıyla geri dönüşümü genellikle ekonomik kazanç sağlamak amacıyla uygulanmaktadır. Bu nedenle geri dönüşüm için yeterli pazar olanaklarının bulunmadığı bir ekonomide, yapım sürecinde oluşan atıkların ayrıımasına yönelik uygulamalar yeterince yer bulamamaktadır (Wang ve diğerleri, 2010). Ayrıca yeterli pazar olanakları olsa bile, geri dönüşümü ekonomik açıdan karlı görülmeyen, beton, ahşap, cam, alçı paneller, asfalt gibi atık malzemelerin geri dönüşüm uygulamalarının yükleniciler tarafından tercih edilmemesi durumu da oluşabilmektedir (European Commission, 2016). Aksel Çiçekçi (2020)'ye göre ülkemizde de şantiyelerde mali kazanç elde etme isteği, geri dönüşüm veya yeniden kullanım amacının en önemli tetikleyicisidir. Mali açıdan yeterli kazanç sağlanılamayacağı düşünülen atıkların geri kazanımı genellikle ihmal edilmektedir. Yapım atığını ayırmanın dolayısıyla geri dönüşümünü sağlamanın; hammadde ve kaynak tüketimini azaltması, malzemelerin hammaddeden üretimi sırasında tüketilecek enerji ile nakliyatı sırasında tüketilecek enerjiyi azaltması, atık döküm sahalarına iletilen atığın dolayısıyla arazi kullanımının azaltılması gibi birçok yararı bulunmaktadır (Wang ve diğerleri, 2010; 
Kartam ve diğerleri, 2004; Tam, 2008b; Yuan ve diğerleri, 2013). Bu nedenle geri dönüşümü ekonomik açıdan karlı görülmeyen yapım atığının da geri kazanımı çevresel açıdan yaygınlaştırılmalıdır (European Commission, 2016).

Yapım atığı şantiyede geri dönüştürülebileceği gibi şantiye dışında bir geri dönüşüm tesisinde de geri dönüştürülebilmektedir. Geri dönüşümün özellikle yoğun nüfuslu ve arz talep dengesinin coğrafi olarak birbirine yakın olduğu alanlarda uygulanması teşvik edilmelidir. Böylelikle gereksinim duyulan malzemenin şantiyeye nakliyatı sırasında açığa çıkacak çevresel etkileri önlenmiş olacaktır (European Commission, 2016).

\subsection{Yapım Süreci Atık Yönetim Sistemi (Sentez)}

Çalışmanın sentez bölümünde, yapım süreci atık yönetiminin sistemli bir şekilde ele alınarak "Yapı üretim sisteminin" bir alt sistemini oluşturan "Yapım sistemi" ile "Atık yönetim sistemi" bütünleştirilmiş ve "Yapım süreci atık yönetim sistemi (YS-AYS)" oluşturulmuştur. Bu bağlamda YS-AYS; "Yapım Sistemi" dolayısıyla "Yapı Üretim Sistemi" ile "Atık Yönetim Sistemi"nin bir alt sistemini oluşturmaktadır. YS-AYS çevresi ile etkileşim içerisinde olan açık bir sistem olarak kurgulanmıştır. YS-AYS'nin sözü geçen etkileşim içinde olduğu sistemlerle ilişkisi Şekil 5'te yer almaktadır.

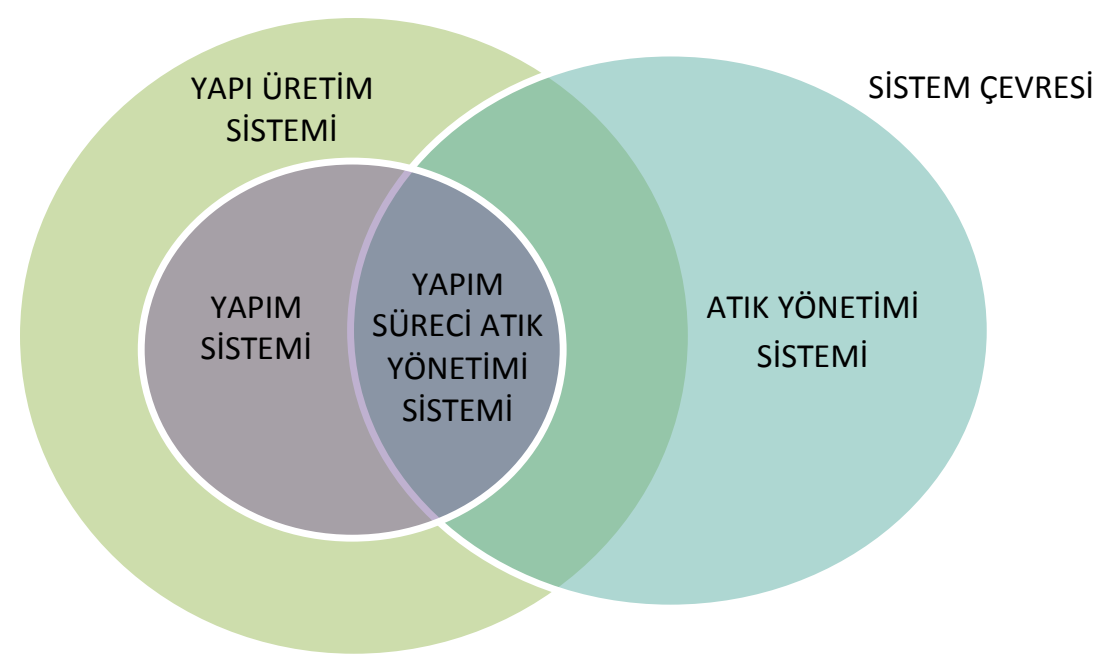

Şekil 5. Yapım süreci atık yönetim sisteminin etkileşim içinde olduğu sistemlerle ilişkisi

YS-AYS, çalışmanın materyal ve yöntem bölümünde açıklanan sistem yaklaşımına uygun olarak ele alınmıştır. Bu bağlamda YS-AYS; sistem hedefleri, sistem kaynakları, sistem bileşenleri, sistem çevresi, sistem yönetimi öğelerinden oluşmaktadır. YS-AYS, genel sistemler teorisi çerçevesinde, girdi, süreç ve çıktı ilişkisi içerisinde kurgulanmış olup (Şekil 6); her bir ögeye ait bilgiler ilgili başlıklar altında açıklanmıştır. 


\begin{tabular}{|c|c|c|}
\hline GiRDi & SÜREÇ & ÇIKTI \\
\hline 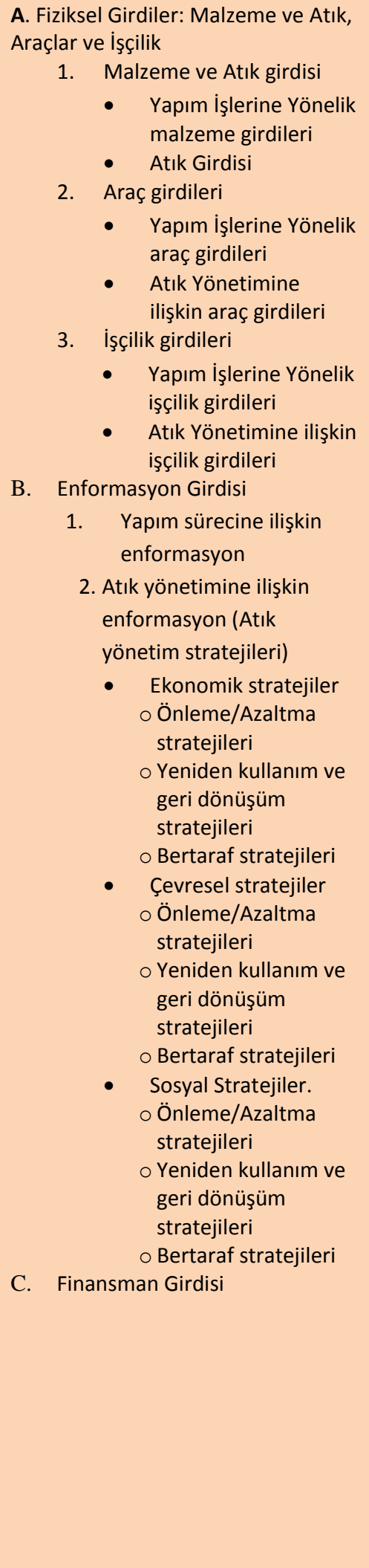 & 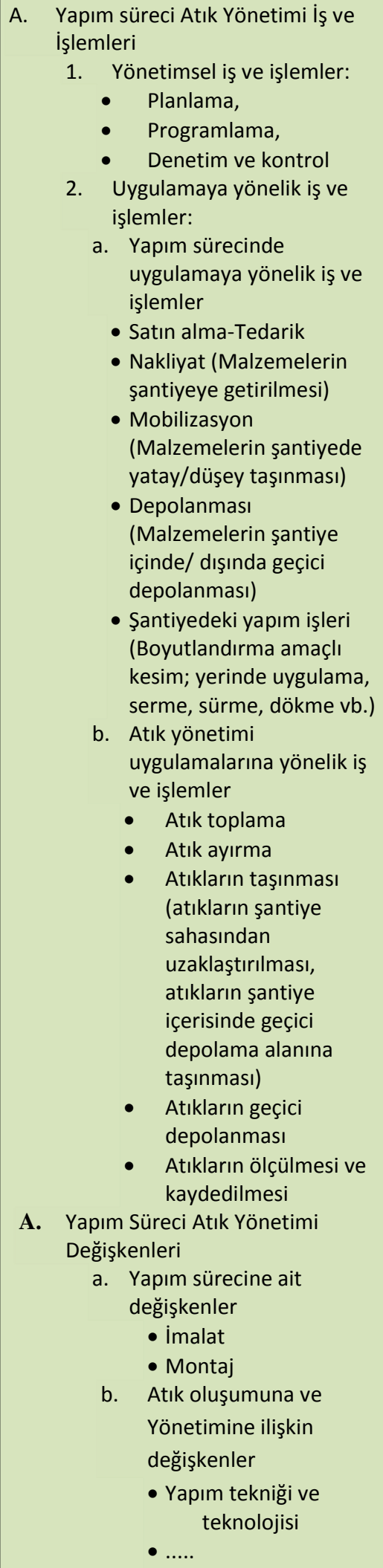 & 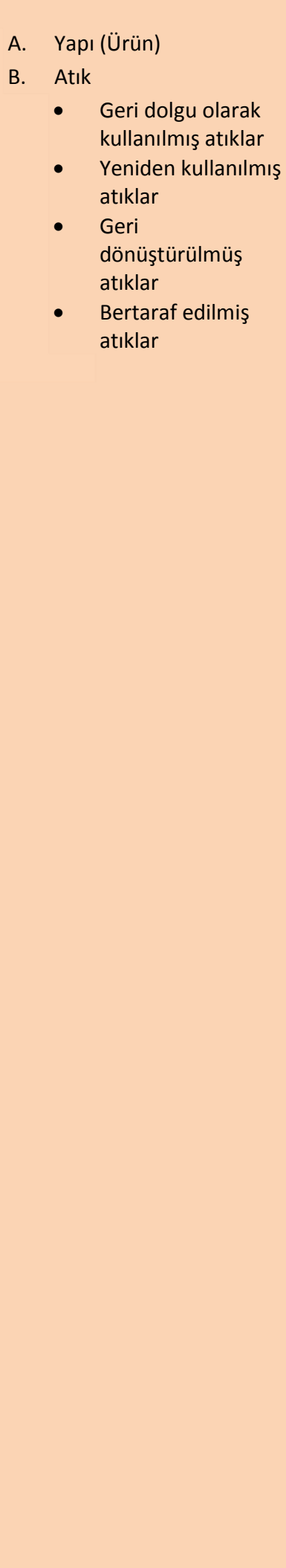 \\
\hline
\end{tabular}

ÇEVRE: Yapım Sistemi, Yapı Üretimi Sistemi ve Atık Yönetimi Sistemi: Kamu otoriteleri, Yapı endüstrisi paydaşları, Yapı sahibi, Tasarımcı ve danışmanlar, Atık endüstrisi paydaşları 


\subsubsection{Yapım süreci atık yönetim sistemi hedefi}

YS-AYS, yapının üretilmesi ile yapım sürecinde atık yönetim uygulamalarının gerçekleştirilmesi hedefine yöneliktir. Bu bağlamda YS-AYS; yapım sırasında ortaya çıkan atıkların AYH'ye uygun olarak öncelikli tercih sırasına göre önlenmesini/azaltılmasını, yeniden kullanımını, geri dönüşümünü ve uygun şekilde bertarafını kapsamaktadır. Yapım sürecinde atıkların önlenmesi/azaltılması, yeniden kullanımı, geri dönüşümü çeşitli stratejilerin uygulanması ile mümkündür.

\subsubsection{Yapım süreci atık yönetim sistemi kaynakları}

YS-AYS kaynakları; Fiziksel girdiler, Enformasyon girdisi, Finansman girdisi ile Karar verici ve uygulayıcılardan oluşmaktadır.

Fiziksel girdiler sistem içerisine etki eden her türlü fiziksel kaynağı ifade etmektedir. Bu fiziksel kaynaklar; yapım işlerinin yürütülebilmesi için gereksinim duyulan malzeme, atık (yapım süreci içerisinde oluşan her türlü atık malzeme), yapım işlerinin yürütülebilmesi için gereksinim duyulan araç ve işçilik ile atık yönetim uygulamalarının yürütülmesi için gereksinim durulan işçilik ve araçları kapsamaktadır. YS-AYS fiziksel girdileri; uygulanan proje, kullanılan yapım tekniği vb. yapım süreci değişkenlerine bağlı olarak farklılaşmaktadır. Bu nedenle sistem girdileri üretilmekte olan yapıya özgü girdilerdir. YS-AYS fiziksel girdilerinden biri olan atık girdisi, herhangi bir geri kazanılmıs malzemeyi ifade etmektedir.

Enformasyon girdisi ise; yapım sürecine ilişkin tüm iş ve işlemler ile yapım sürecinde atık yönetimine ilişkin tüm iş ve işlemlere yönelik gereksinim duyulan her türlü bilgiyi kapsamaktadır. Atıkların azaltılması; yeniden kullanılması, geri dönüştürülmesi ile uygun şekilde bertafına yönelik her türlü bilgi bu kapsamda yer almakta olup, atık yönetimine ilişkin bilgiler atık yönetim stratejileri olarak ifade edilmiştir. Atık yönetim stratejileri yapım sürecinde atık yönetim uygulamalarında çevresel, ekonomik ve sosyal açıdan sürdürülebilirliğin sağlanabilmesi için yararlanılması ön görülen her türlü (yönetmelikler, literatür verileri, veri tabanları vb.) bilgiyi ifade etmektedir. Bu bağlamda Atık yönetim stratejilerine örnek olarak, çevresel nitelikte bir atık azaltma stratejisi olan; şantiyeye iletilen yapı ürünlerinin yapımda kullanılmasına kadar geçen süre içerisinde geçici depolanması amacıyla, depolama alanında ısı, nem, rüzgâr vb. etmenler gözetilerek, ürünler zarar görmeyecek şekilde uygun koşullarda saklanması ve şantiyelerdeki depolama koşullarının iyileştirilmesi verilebilir. Bir diğer örnek ise; bir yeniden kullanım stratejisi olan; Koruma amaçlı geçici olarak kaplı veya boyalı yüzeyler üzerinde kullanılacak karton kâğıt ve plastik gibi malzemelerin, öncelikle ambalaj atıklarından elde edilmesi verilebilir.

Finansman girdisi, YS-AYS içerisinde yapım sürecine ilişkin finansman girdisi ve atık yönetim iş ve işlemlerinin yürütülmesine ilişkin finansman girdilerini kapsamakta olup, gereksinim duyulan parasal kaynağı ifade etmektedir. Şantiyelerde atıkların ayrıştırıması gibi atık yönetimine ait işlemler, ek işçi çalıştırılması veya fazladan ekipman kullanımı gerektirebileceğinden, ekonomik yönden de ele alınması uygun olacaktır.

\subsubsection{Yapım süreci atık yönetim sistemi bileşenleri}

YS-AYS bileşenleri; girdiler, süreçler, çıktılar ile geri besleme ve kontrol olarak sıralanmaktadır. Yapım sistemi girdileri (kaynakları) ilgili başık altında açıklanmış olup, YS-AYS bileşenlerinden süreç, çıktı ile geri besleme ve kontrol akışta ele alınmıştır. Sistem değişkenleri ise süreç içerinde aktarılmıştır.

YS-AYS Süreci, yapım süreci ile yapım sürecinde atık yönetim sürecini içermektedir. Bu bağlamda YSAYS süreci, Yapım süreci Atık Yönetimi İş ve İşlemleri ile Yapım Süreci Atık Yönetimi Değişkenleri olarak iki başlık altında toplanmıştır. Yapım süreci Atık Yönetimi iş ve işslemleri yapım sürecinde atık yönetimine ilişkin yönetimsel ve uygulamaya yönelik tüm iş ve işlemleri kapsamaktadır. Yönetimsel iş̧ ve iş̧lemler; yapım süreci iş ve işlemleri ile atık yönetimine ilişkin iş ve işlemlerin planlanması, programlanması ile denetim ve kontrolü işlerini kapsamaktadır. Uygulamaya yönelik iş ve işlemler ise; Yapım Sürecinde Uygulamaya Yönelik iş̧ ve işlemler (satın alma-tedarik, nakliyat, şantiyedeki yapım işleri vb.) ve Atık Yönetimi Uygulamalarına Yönelik iş̧ ve Iş̧lemler (atık toplama, ayırma vb.) olarak iki alt başlık altında gruplandırılmıştır. Yapım Süreci Atık Yönetimi Değişkenleri ise; yapım sürecine ait imalat 
ve montaj değişkenleri ile atık oluşumu ve atık oluşum miktarına etki eden değişkenler (projenin türü, kullanılan malzemeler, yapım tekniği ve teknolojisi, yerel piyasa koşulları, uygulama ekibinin mesleki yetenekleri, iş̧̧ilik vb.) olarak belirlenmiştir.

YS-AYS Çıktıları yapım sürecinin ürünü olan "yapı" ile yapım sürecinin fiziksel çıktılarından biri olan "atıktan" oluşmaktadır. Sistem içerisinde atıklar; geri dolgu olarak kullanılmış atıklar, yeniden kullanıımış atıklar; geri dönüştürülmüş atıklar; bertaraf edilmiş atıklar olarak sınıflandııılmıştır.

YS-AYS'de geri-besleme ve kontrol; yeniden kullanım ve/veya geri dönüşüm yoluyla elde edilen geri kazanılmış malzemelerin kendilerinden beklenilen performansları sağlayıp sağlayamama durumunun kontrolü ile yapı ürününün çeşitli performanslar ile ilgili yönetmelik ve standartlara uygunluğunun kontrolü olarak belirlenmiştir.

\subsubsection{Yapım süreci atık yönetim sistemi yönetimi}

YS-AYS yönetimi yapım sürecine ait yönetimsel iş ve işlemler ile atık yönetimine ait yönetimsel iş ve işlemleri kapsamaktadır.

Yapım sürecinde atık yönetimine ilişkin iş ve işlemlerin yürütülebilmesi için çeşitli araçlardan yararlanılmaktadır. Bu araçlar; atık yönetim planı, şablonları ve rehberleri, atık veri toplama ve denetim araçları, atık tahmin araçları, çevresel değerlendirme araçları ve atık coğrafi bilgi sistemleri (CBS) araçları olarak sınıflandırılabilir (Akinade ve diğerleri, 2018).

\subsubsection{Yapım süreci atık yönetim sistemi çevresi}

YS-AYS; Yapı üretim sistemi, Yapım sistemi ve Atık yönetim sisteminin birer alt sistemini oluşturmakta olup, bu bağlamda alt sistemini oluşturduğu sistemler YS-AYS'nin çevresi olarak tanımlanabilir. YS-AYS çevresi sözü geçen sistemlerin çevrelerinin kesişiminden oluşan öğeler içermekte olup, bu öğeler;

- Kamu otoriteleri: Yasal düzenlemelerden sorumlu kurumlar (Yerel yönetimler, Bakanlıklar vb.)

- Yapı endüstrisi paydaşları: Yönetici, Yüklenici, Alt yüklenici, Tedarikçi, İmalatçı-Üretici, Tasarımcı, Proje yöneticisi, Yapım yöneticisi, Kalite kontrolcü, Güvenlik koordinatörü ve Danışmanlar (TSE-EN ISO 12006-2)

- Yapı sahibi, tasarımcı ve danışmanlar: Mimarlar, mühendisler vb.

- Atık endüstrisi paydaşları; Atık yüklenicileri, Atık toplayıcısı, Tehlikeli atık toplayan firmalar, Geri kazanılmış malzeme-bileşen üreticisi vb. olarak özetlenebilir.

\section{Sonuç ve Öneriler (Değerlendirme)}

Bu çalışmada yapı üretimi, yapım süreci ve atık yönetimi konuları sistem yaklaşımıyla ele alınarak bir "Yapım Süreci Atık Yönetim Sistemi” önerilmiştir. Çalışma analiz, sentez ve değerlendirme olmak üzere üç aşamada gerçekleştirilmiştir. Çalışmanın analiz aşamasının ilk adımında; yapı üretim süreci ile yapım süreci açıklanmış ve literatür bilgisine dayalı olarak yapı üretimi sistemi ile yapım sistemi girdi-süreççıktı ilişkisi içerisinde modellenmiştir. Yapı üretimi sistemi ile yapım sistemi öğelerini oluşturan sistem hedefleri, sistem kaynakları, sistem bileşenleri, sistem çevresi ve sistem yönetimi ilgili başlıklar altında detaylandırılmıştır. Analiz aşamasının ikinci adımında ise; yapım sürecinde atık yönetim sisteminin oluşturulmasına yönelik temel oluşturacak kavramlara ilişkin teorik bilgilere ve açıklamalara yer verilmiştir. Öncelikle Atık, Atık Yönetimi ve Atık Yönetim Hiyerarşisi kavramları açıklanmış ve yapı endüstrisi kaynaklı bir katı atık türü olan yapım atığının içerik, nitelik ve oluşum nedenleri aktarılmıştır. Şantiyelerde mevcut atık yönetim uygulamaları ile yapım süreci atık yönetimiyle ilgili literatürde yer alan ilke ve stratejiler ele alınmıştır. Çalışmanın sentez aşamasında ise; çalışmanın analiz aşamasında elde edilen bilgilere dayalı olarak, yapı üretimi sisteminin bir alt sistemini oluşturan yapım sistemi ile atık yönetim sistemi bütünleştirilmiş ve "Yapım Süreci Atık Yönetim Sistemi" (YS-AYS) oluşturulmuştur. Bu bağlamda çalışmadan elde edilen sonuçları aşağıdaki şekilde özetlemek mümkündür.

Yapı üretimi; birden fazla aktörün ve nesnenin sürecin farklı aşamalarında dahil olduğu fiziksel çevreyi düzenlemek için yürütülen örgütlü bir çabadır. Yapılar ise; yapı üretimi sürecinin bir çıktısı olup, birbirleri ile ilişkili ve entegre birçok sistem ve alt sistemin parçasını oluşturmaktadır. Sistemler 
aralarında anlamlı ilişkiler bulunan birbirlerine bağımlı öğeleri içeren kavramsal veya fiziksel varlıklar ya da bütünlerdir. Yapı üretimi sisteminin alt sistemlerinden birini oluşturan "Yapım sistemi"; "tüm yapı elemanlarının ve bu elemanların bir araya gelme olasılıklarının toplamı"; "binayı oluşturan elemanların bir araya getirilmesinde izlenen süreç" ve "uygulanan üretim, teknoloji, kural ve yöntemler" olarak tanımlanmaktadır. Yapım süreci ise yapım sisteminin bir öğesi olup, yapım sürecinin en görünür çevresel etkilerinden biri atık oluşumudur. Atıklar uygun şekilde yönetilmesi gereken nesnelerdir. Atık yönetimi; uygun depolama, toplama, taşıma ve bertaraf teknikleri ve sistemlerinin uygulanmasını kapsayan bütüncül bir yaklaşımdır. Atık yönetiminde çeşitli stratejiler uygulanmakta olup, bu stratejilerden Atık Yönetim Hiyerarşisi uluslararası alanda yaygın olarak kabul edilen çevresel açıdan tercih sırasına dayalı bir yaklaşımdır. AYH'ye göre atığın önlenmesi/azaltılması öncelikli olarak tercih edilmelidir, atığın önlenmesi/azaltılması mümkün değilse, daha sonra tercih edilmesi gereken uygulama yeniden kullanımdır. Yeniden kullanımın mümkün olmadığı durumlarda ise, bir sonraki uygulama olarak geri dönüşüm tercih edilmelidir.

Yapım sürecinde atık oluşum miktar ve içerikleri uygulanan projenin türü, proje alanına ait değişkenler, şantiyede kullanılan yapım teknolojisi ve tekniği, işçilik vb. birçok parametreye bağlı olarak değişkenlik göstermektedir. Şantiyenin bu çok değişkenli yapısı atık yönetimi konusunun anlaşılabilirliği ve uygulanabilirliği açısından önemli bir kısıt oluşturmaktadır. Dolayısıyla yapım sisteminin alt ve üst sistemlerle ilişki içerisinde olacak şekilde kurgulanarak atık yönetimi ile ilişkilendirilmesi, yapım sürecinde atık yönetim uygulamalarının anlaşılabilmesi ve etkin bir şeklide yürütülebilmesi açısından önem taşımaktadır.

YS-AYS yapım sistemi ögeleri ile atık yönetimine ilişkin ögeleri kapsar şekilde, girdi-süreç-çıktı ilişkisi içerisinde modellenen bir sistemdir. YS-AYS, yapım süreci ürününün (yapının) üretilmesi ile yapım sürecinde atık yönetim uygulamalarının etkin bir şekilde gerçekleştirilmesi hedefine yöneliktir. YSAYS'nin hedefleri yapım sırasında ortaya çıkan atıkların AYH'ye uygun olarak öncelikli tercih sırasına göre önlenmesi/azaltılması, yeniden kullanımı, geri dönüşümü ve uygun şekilde bertarafını kapsamaktadır. Bu bağlamda YS-AYS'nin şantiyelerde atık yönetiminin sistemli bir şekilde uygulanmasına katkı sağlayacağı düşünülmektedir. YS-AYS sistem çevresi (üst ve alt sistemler) ile etkileşim içerinde olan açık bir sistem olma özelliği göstermekte olup; yapı üretimi sistemi, yapım sistemi ve atık yönetimi sisteminin kapsamında yer alan bir alt sistem niteliğindedir. Aynı zamanda YSAYS, şantiyenin çok aktörlü ve çok değişkenli yapısı ile atık yönetim işlemlerinin çeşitliliği nedeniyle birden fazla alt sistemi bünyesinde barındırma özelliği göstermektedir. Bu bağlamda gelecek çalışmalarda YS-AYS'nin alt sistemleri sistem yaklaşımı çerçevesinde ele alınabilir. Bu alt sistemlerin; yeniden kullanım sistemi, geri dönüşüm sistemi ve bertaraf sistemi vb. olarak tanımlanarak, girdi-süreççıktı ilişkisi içerisinde kurgulanması yapım süresinde atık yönetiminin uygulanabilirliğinin kolaylaştırılması açısından önemli rol oynayacağı düşünülmektedir.

\section{Teşekkür ve Bilgi Notu}

Bu makalede çalışmanın analiz bölümü, İstanbul Teknik Üniversitesi Lisansüstü Enstitüsü Mimarlık Ana Bilim Dalı́nda Yapı Bilimleri Doktora Programı'nda tamamlanan Doktora tezi literatür verilerinden yararlanılarak üretilmiştir. Sentez ve değerlendirme bölümleri özgündür.

Makalede, ulusal ve uluslararası araştırma ve yayın etiğine uyulmuştur. Çalışmada etik kurul izni gerekmemiştir.

\section{Kaynaklar}

Ackoff, R. L., Sasinieni, M. W. (1968). Fundamentals of operations research. John Wiley and Sons.

Aksel Çiçekçi H. (2020). Yapılarda yapım süreci çevresel etkisinin azaltılmasına yönelik atık yönetim modeli önerisi (Doktora tezi). İstanbul Teknik Üniversitesi, Lisansüstü Eğitim Enstitüsü, İstanbul.

Aksoy, Ö. (1974). Uyum sürecinin mimarlık sistemi içinde örneklenmesi. Karadeniz Teknik Üniversitesi Yayınları.

Aral, N. (1979). Yapı üretiminde proje yönetimi için üretkenlik kavramına dayalı bir değerlendirme modeli (Doktora tezi). İstanbul Teknik Üniversitesi, Fen Bilimleri Enstitüsü, İstanbul. s.50-51 
Atık Yönetimi Yönetmeliği. (2015). T. C. Resmi Gazete, 29314, 2 Nisan 2015.

Balanlı, A. (1997). Yapıda Ürün Seçimi, Yıldız Üniversitesi Mimarlık Fakültesi Eğitim ve Kültür Hizmetleri Derneği Yayını.

Bayazıt, N. (1994). Endüstri Ürünlerinde ve Mimarlıkta Tasarlama Metodlarına Giriş, Literatür Yayınları, İstanbul. s.269.

Baytop, F. (2019). Şantiye Yönetimi, YEM yayınları 6. baskı S.24.

Begum, R. A., Siwar, C., Pereira, J. J., \& Jaafar, A. H. (2006). A benefit-cost analysis on the economic feasibility of construction waste minimisation: the case of Malaysia. Resources, conservation and recycling, 48 (1), 86-98.

Berköz, S. (1975). Yapım’da sistemler yaklaşımı. İstanbul Teknik Üniversitesi Mimarlık Fakültesi.

Chang, N., Pires, A. (2015). Sustainable solid waste management: A systems engineering approach. Hoboken, New Jersey: John Wiley \& Sons, Inc.

Ching Francis, D. K. (2008). Building Construction Illustrated. John Wiley and Sons, Fourth Edition

Chong, W. K., Hermreck, C. (2010). Understanding transportation energy and technical metabolism of construction waste recycling. Resources, conservation and recycling, 54 (9), 579-590.

Christensen, T. H. (Ed.). (2011). Solid waste technology and management (Vol. 2). Chichester, West Sussex, UK: Wiley.

Chudley, R., Greeno, R. (2006). Advanced construction technology. Pearson Education Limited. p.5

Çetiner, O. (2007) Şantiye Yönetimi Dersi Ders Notları, Yıldız Teknik Üniversitesi. Mimarlık Fakültesi, Mimarlık Bölümü.

Çevre ve Şehircilik Bakanlığı (ÇŞB). (2017). Ulusal Atık Yönetimi ve Eylem Planı 2023. Erişim adresi (24.01.2020):https://webdosya.csb.gov.tr/db/cygm/haberler/ulusal_at-k_yonet-m-eylem_plan--20180328154824.pdf

Ekanayake, L. L. ve Ofori, G. (2004). Building waste assessment score: design-based tool. Building and Environment, 39 (7), 851-861.

Ekholm, A., Häggström, L. (2011). Building classification for BIM-Reconsidering the framework. CIB.

Eriç, M. (2016). Yapı fiziği ve Malzemesi. Literatür yayınları. 4. basım, s.11

European Commission. (2016). EU Construction and Demolition Waste Management Protocol, September, 2016. Erişim adresi (07.06.2018): https://ec.europa.eu/docsroom/documents/20509/attachments/1/translations/en/renditions /native

European Commission. (2018). EU Construction and Demolition Waste Protocol and Guidelines. Erişim adresi (15.05.2020): https://ec.europa.eu/growth/content/eu-construction-and-demolitionwaste-protocol-0_en

European Parliament and Council. (2008). Directive 2008/98/EC of the European Parliament and of the Council of 19 November 2008 on waste and repealing certain directives. Official Journal of European Union, L312, pp. 3-30.

European Parliament and Council. (2018). Directive 2008/851 of the European Parliament and of the Council of 30 May 2018 amending Directive 2008/98/EC on waste. Official Journal of European Union, L 150/109.

Eurostat (2012). Eurostat Waste Statistics. Erişim adresi (08.05.2020): https://ec.europa.eu/eurostat/data/database 
Eurostat (2016). Eurostat Waste Statistics. Erişim adresi (08.05.2020): https://ec.europa.eu/eurostat/statisticsexplained/index.php?title=File:Waste_generation_by_ economic_activities_and_households,_EU-28,_2016_(\%25).png.

Faniran, O. O. ve Caban, G. (1998). Minimizing waste on construction project sites. Engineering, construction and architectural management, 5 (2), pp. 182-188.

Galipoğulları, N. (2016). Uygulamalı Toplam İnşaat Yönetimi. Birsen Yayınevi. s.151-270

Gálvez-Martos, J. L., Styles, D., Schoenberger, H., Zeschmar-Lahl, B. (2018). Construction and demolition waste best management practice in Europe. Resources, Conservation and Recycling, $136,166-178$.

Gálvez-Martos, J. L., and Istrate, I. R. (2020). Construction and demolition waste management. Pacheco-Torgal, F. (Ed.) Introduction to advances in construction and demolition waste. Advances in Construction and Demolition Waste Recycling, 51-66

Gavilan, R. M. ve Bernold, L. E. (1994). Source evaluation of solid waste in building construction. Journal of construction engineering and management, 120 (3), 536-552.

Goodhew, S. (2016). Sustainable construction processes: A resource text. John Wiley \& Sons. p. 174

Gorgolewski, M., Straka, V., Edmonds, J. ve Sergio, C. (2006). Facilitating Greater Reuse and Recycling of Structural Steel in the Construction and Demolition Process. Ryerson University. Can. Inst. Steel Construct.

Hinze, J. (2012). Construction planning and schedulin. Upper Saddle River, NJ: Pearson/Prentice Hall.

Huang, B., Wang, X., Kua, H., Geng, Y., Bleischwitz, R., Ren, J. (2018). Construction and demolition waste management in China through the 3R principle. Resources, Conservation and Recycling, 129, 3644.

Kanoğlu, A. (t.y.). Yapım Yönetiminde Zaman Yönetimi ve Planlama Teknikleri. ITÜ Mimarlık. Böl. Yapı Üretiminde Zaman Yönetimi Ders Notları. Erişim Adresi (09.01.2020): https://web.itu.edu.tr/ kanoglu/crs-sry-ss-techniques.pdf.

Kartam, N., Al-Mutairi, N., Al-Ghusain, I. ve Al-Humoud, J. (2004). Environmental management of construction and demolition waste in Kuwait. Waste management, 24 (10), pp. 1049-1059.

Li, Y. (2013). Developing a sustainable construction waste estimation and management system. (Ph.D. Thesis). Hong Kong University of Science and Technology, Hong Kong.

Llatas, C. (2013). Methodsforestimatingconstructionanddemolition (C\&D) waste. In Handbook of recycledconcreteanddemolitionwaste (pp. 25-52). Woodhead Publishing. S-32

Lou, E. C. W., Goulding, J. S. (2008). Building and construction classification systems. Architectural Engineering and Design Management, 4 (3-4), 206-220.

Ministry of Land, Infrastructure, Transport, Tourism (MLIT). (2019). White Paper on Land, Infrastructure, Transport and Tourism in Japan. Erişim adresi (04.05.2020); https://www.mlit.go.jp/common/001325161.pdf.

Osmani, M. (2012). Construction waste minimization in the UK: current pressures for change and approaches. Procedia-Social and Behavioral Sciences, 40, 37-40.

Osmani, M., Glass, J. ve Price, A.D. (2008). Architects' perspectives on construction waste reduction by design. Waste management, 28 (7), pp. 1147-1158.

Osmani, M., and Villoria-Sáez, P. (2019). Current and emerging construction waste management status, trends and approaches. Letcher, T. M., Vallero, D. A. (Ed.) In Waste: A Handbook for Management Academic Press. pp. 365-380.

Özkan, E. (1976). Yapım Sistemlerinin Seçimi İçin Bir Yöntem (Doktora tezi). İstanbul Teknik Üniversitesi, Mimarlık Fakültesi, İstanbul. 
Peng, C. L., Scorpio, D. E., Kibert, C. J. (1997). Strategies for successful construction and demolition waste recycling operations. Construction Management \& Economics, 15 (1), 49-58.

Pichtel, J. (2005). Waste management practices: municipal, hazardous, and industrial. CRC press.

Poon, C. S., Ann, T. W., ve Ng, L. H. (2001). On-site sorting of construction and demolition waste in Hong Kong. Resources, conservation and Recycling, 32 (2), pp. 157-172.

Poon, C. S., Yu, A. T. ve Jaillon, L. (2004a). Reducing building waste at construction sites in Hong Kong. Construction Management and Economics, 22 (5), pp. 461-470.

Poon, C.S., Yu, A. T. W., Wong, S. W. ve Cheung, E. (2004b). Management of construction waste in public housing projects in Hong Kong. Construction Management \& Economics, 22 (7), pp. 675689.

Sey, Y., Orhon, I., Aral, N., Cansun, O., Özüekerem, Ş., Giritli, H., Sözen, Z., Çırakçı, M. (1987). Çağdaş Yapım Sistemleri. ITÜ Gemi İnşaat Fakültesi Ofset Atölyesi

Tam, V. W. (2008b). Economic comparison of concrete recycling: A case study approach. Resources, Conservation and Recycling, 52 (5), pp. 821-828.

Tam, V. W., Tam, C. M. (2005). Evaluations of existing waste recycling methods: a Hong Kong study. Building and Environment, 41(12), pp. 1649-1660.

Tam, V. W., Tam, C. M. (2006). A review on the viable technology for construction waste recycling. Resources, conservation and recycling, 47 (3), pp. 209-221.

Tam, V. W. (2009). Comparing the implementation of concrete recycling in the Australian and Japanese construction industries. Journal of Cleaner production, 17(7), 688-702.

Tchobanoglous, G., Theisen, H. ve Vigil, S. (1993). Integrated solid waste management: Engineering principles and management Issues. McGraw-Hill. p.628

TSE-EN ISO 12006-2. (2020). Bina yapımı-Yapım işlerine ilişkin bilgilerin organizasyonu - Bölüm 2: Sınıflandırma için çerçeve bilgi (ISO 12006-2:2015). Erişim adresi (01.01.2020): https://kutuphane.itu.edu.tr/

Türkçü, H. Ç. (2004). Yapım: ilkeler-malzemeler-yöntemler-çözümler. Birsen Yayınevi.

European Commission. (2020). European commission official web site. Erişim adresi (10.04.2020, 08.08.2020): https://ec.europa.eu

UNEP. (2005). United nations environment programme official web site. Erişim adresi (08.10.2015): http://www.unep.org

TDK (2020). Türk dil kurumu resmi web sitesi. Erişim adresi (02.02.2020): http://tdk.gov.tr/>, erişim tarihi

EPA (2021). United States Environmental Protection Agency official web site. Erişim adresi (24.05.2021): https://www.epa.gov/

Wang, J., Yuan, H., Kang, X., Lu, W. (2010). Critical success factors for on-site sorting of construction waste: a China study. Resources, conservation and recycling, 54 (11), 931-936.

Xiao, X. W., Feng, D. K., Tian, W. (2015). Present situation and suggestions on recycling and utilization of construction waste in China. Constr. Tech., 44, 6-8.

Yuan, H. (2013b). Key indicators for assessing the effectiveness of waste management in construction projects. Ecological Indicators, 24, pp. 476-484

Yuan, H., Lu, W., Hao, J. J. (2013). The evolution of construction waste sorting on-site. Renewable and Sustainable Energy Reviews, 20, pp. 483-490. 